\title{
Molecular Mechanisms of Apoptosis and Roles in Cancer Development and Treatment
}

\author{
Samira Goldar',2, Mahmoud Shekari Khaniani' ${ }^{1}$, Sima Mansoori Derakhshan', \\ Behzad Baradaran ${ }^{2 *}$
}

\begin{abstract}
Programmed cell death (PCD) or apoptosis is a mechanism which is crucial for all multicellular organisms to control cell proliferation and maintain tissue homeostasis as well as eliminate harmful or unnecessary cells from an organism. Defects in the physiological mechanisms of apoptosis may contribute to different human diseases like cancer. Identification of the mechanisms of apoptosis and its effector proteins as well as the genes responsible for apoptosis has provided a new opportunity to discover and develop novel agents that can increase the sensitivity of cancer cells to undergo apoptosis or reset their apoptotic threshold. These novel targeted therapies include those targeting anti-apoptotic Bcl-2 family members, p53, the extrinsic pathway, FLICE-inhibitory protein (c-FLIP), inhibitor of apoptosis (IAP) proteins, and the caspases. In recent years a number of these novel agents have been assessed in preclinical and clinical trials. In this review, we introduce some of the key regulatory molecules that control the apoptotic pathways, extrinsic and intrinsic death receptors, discuss how defects in apoptotic pathways contribute to cancer, and list several agents being developed to target apoptosis.
\end{abstract}

Keywords: Apoptosis - apoptotic pathways - cancer - treatment target

Asian Pac J Cancer Prev, 16 (6), 2129-2144

\section{Background}

The term 'apoptosis' has long been utilized as a synonym for programmed cell death (PCD) since the seminal article of Kerr et al., published in 1972 (Kerr et al., 1972). Apoptosis, or type 1 cell death, is a significant terminal pathway for cells of multicellular organisms, and causes a diversity of biological events such as proliferation/homeostasis, differentiation, development and elimination of harmful cells as a protective strategy to remove infected cells (Elmore, 2007). Apoptosis is fundamentally distinct from other types of cell death based on its incidence, morphology, and biochemistry. Particular morphological alterations of apoptotic cells include nuclear condensation and fragmentation, cell shrinkage, dynamic membrane blebbing, and loss of adhesion to extracellular matrices or to neighbors. Biochemical alterations consist of chromosomal DNA cleavage into internucleosomal fragments, phosphatidylserine externalization, and activation of a family of proteases recognized as the caspases (Ouyang et al., 2012). A minor dysfunction of PCD results in various pathological disorders in humans such as various cancers (Sun and Peng, 2009). Apoptosis is a cellular procedure that is regulated by different groups of executioner and regulatory molecules (Mukhopadhyay et al., 2014) and their aberrant function is fundamental to the growth of tumors and the development of anticancer drug resistance. Therefore, apoptosis has become one of the prime molecular targets for drug discovery and development, particularly for diseases like cancer.

\section{Mechanisms of Apoptosis}

Apoptosis is recognized as the most important form of cell death and its molecular signaling pathway is well known. Identification of apoptotic mechanisms is critical and facilitates the understanding of the pathogenesis of diseases as a result of dysfunctional apoptosis. This, in turn, may assist in developing new drugs that target specific apoptotic pathways or genes. In mammals, there are two central apoptotic pathways: the extrinsic pathway (death receptor mediated pathway) and the intrinsic pathway (mitochondrial mediated pathway) (Figure 1) (Hassen et al., 2012). Moreover, besides these two pathways, there are additional pathways of caspase activation that are less well known, including an initiator role of caspase-12 or caspase-2 in apoptosis activated by endoplasmic reticulum stress (ER) (Szegezdi et al., 2006). The perforin/granzyme pathway is another pathway that involves T-cell mediated cytotoxicity. This pathway can induce apoptosis via either granzyme A or granzyme B. All these apoptotic pathways (extrinsic, intrinsic, and granzyme B pathways) converge on the same terminal or execution pathway (Jin and El-Deiry, 2005). The key regulatory proteins in both

${ }^{1}$ Department of Biochemistry and Clinical Labratorary, Division of Medical Genetics, Faculty of Medicine, ${ }^{2}$ Immunology Research Center, Tabriz University of Medical Sciences, Tabriz, Iran*For correspondence: behzad_im@yahoo.com 
intrinsic and extrinsic pathways are the caspases ( $\mathrm{Li}$ and Yuan, 2008). Three groups of mammalian caspases exist on the basis of specific functions in different pathways, including developmental, inflammatory, and apoptotic pathways (Weyhenmeyer et al., 2012). Thus, some caspases, such as caspase-1, do not have a role in apoptosis execution, while several caspases have dual roles both in nonapoptotic and apoptotic signaling. In addition, caspases are classified as initiator (caspase-8 and -9) and effector or executioner caspases (caspase-3, -6 and -7), based on their position in apoptotic signaling cascades $(\mathrm{Hu}$ et al., 2013). The initiator caspases, which are activated by autocleavage, sequentially cleave and activate the downstream "executioner" caspases. Subsequently, the executioner caspases cleave essential cellular components to orchestrate the proteolytic dismantling of the cell (Green and Evan, 2002).

\section{The extrinsic death receptor pathway}

Apoptotic signaling through the extrinsic pathway begins with the attachment of extracellular ligands, for example, tumor necrosis factor (TNF), Fas ligand (Fas-L), and TNF-related apoptosis-inducing ligand (TRAIL) to the extracellular domain of transmembrane receptors [death receptors, i.e. the type 1 TNF receptor (TNFR1), Fas (also called CD95/Apo-1), TRAIL receptors] (Jin and El-Deiry, 2005; Guicciardi and Gores, 2009). Upon binding of ligand to receptor, the death receptors bind via their intracellular death domain with a corresponding protein motif in adapter proteins such as Fas-associated death domain (FADD) and TNF receptor-associated death domain (TRADD). These adaptor proteins also have another protein interaction domain, called the Death Effector Domain (DED). Pro-caspase-8 also contains DED, which interacts with the DED of FADD (Khosravi-Far and Esposti, 2004).At this time, a deathinducing signaling complex (DISC) is developed, leading to auto-catalytic activation of procaspase- 8 (Boatright et al., 2003). Active caspase- 8 activates effector/executioner caspases, which cause cell death by damage or destruction of the nucleus and other intracellular structures (Jin and El-Deiry, 2005).

\section{The intrinsic mitochondrial apoptosis pathway}

A number of internal stimuli cause an increase in mitochondrial membrane permeability (Kroemer et al., 1998). These different stressors are recognized by several intracellular proteins that send the signal to the mitochondria, ending in Mitochondrial Outer Membrane Permeabilization (MOMP) (Chipuk et al., 2006). MOMP is most commonly mediated via a variety of proteinmembrane and protein-protein interactions of the B-cell lymphoma 2 protein (BCL-2) family (Chipuk et al., 2004). The Bcl-2 family of proteins comprise 25 pro- and antiapoptotic members; cell health relies on the balance among these pro-apoptotic and anti-apoptotic $\mathrm{Bcl}-2$ proteins. Bcl2-family members contain one or more Bcl-2 homology $\mathrm{BH})$ domains, those that have four BCL-2 homology domains BCL-2, MCL-1, A1/Bfl-1, Bcl-B/Bcl2L10, and BCL-xL (BCL extralarge) are anti-apoptotic, which block apoptosis by inhibiting their pro-apoptotic counterparts via protein-protein interactions (Czabotar et al., 2014). The pro-apoptotic family members are classified into two further subgroups, according to whether they have multiple BH domains (effector proteins) including: BAX, $\mathrm{BAK}$, and BOK (BCL-2 related ovarian killer) or whether they contain only the BH3 domain, to include BID, BIM, PUMA, NOXA, BIK, BAD, HRK, and BMF (Chipuk et al., 2006; Czabotar et al., 2014).

Following apoptotic stimuli, the $\mathrm{BH} 3$-only proteins (BAX and BAK) activate and insert into the outer mitochondrial membrane to cause the release of cytochrome $\mathrm{c}$ and other mitochondrial proteins, including apoptosis-inducing factor (AIF) and endonuclease G, Smac/DIABLO (second mitochondria-derived activator of caspase/direct IAP-binding protein with low PI) and the serine protease Omi/HtrA2 (high-temperature requirement protein A2) (Acehan et al., 2002; Chipuk et al., 2006). Subsequently, in the cytosol, cytochrome c interacts with apoptosis protease-activating factor 1 (Apaf1 ), and forms a complex recognized as the apoptosome (Zou et al., 1997). The apoptosome, a multi-protein platform comprising a seven-spoke ring-shaped complex (Yuan and Akey, 2013), leads to activation of initiator caspase (usually caspase-9), which in turn activates executioner caspase- 3 and initiates a caspase cascade, which eventually leads to demolition of the cell (Jin and El-Deiry, 2005). AIF and endonuclease G can both promote caspase-independent cell death through inducing chromatin condensation and cleavage of nuclear DNA(Li et al., 2001; Sevrioukova, 2011). Besides the fundamental role of AIF in the execution of caspase-independent cell death, AIF has emerged as an important protein for cell survival (Sevrioukova, 2011). Other mitochondrial proteins that released in the cytosol are Smac/DIABLO and $\mathrm{Omi} / \mathrm{HtrA} 2$, which provides an additional mechanism for caspase activation. Smac/DIABLO and Omi/HtrA2, interact and antagonize Inhibitor of Apoptosis (IAP) proteins and promote caspase activation (Gustafsson and Gottlieb, 2008; Vande Walle et al., 2008).

\section{Role of Apoptosis in Cancer}

Appropriate apoptotic signaling is fundamentally important to preserving a healthy balance between cell death and cell survival and in maintaining genome integrity, as highlighted by the establishment of the evasion of apoptosis as a prominent hallmark of cancer (Plati et al., 2011). Apoptotic pathways can be altered by cancer cells transcriptionally, translationally, and post translationally. Significantly, these mechanisms are not exclusive and cancer cells can use a number of diverse strategies to evade apoptosis (Fulda, 2010). Several proteins have been described that apply pro- or antiapoptotic activity in the cell. The ratio of these pro-and anti-apoptotic proteins plays an important role in the regulation of cell death, and disruption in the balance of pro- and anti-apoptotic proteins has been established to contribute to carcinogenesis by reducing apoptosis in malignant cells. For example, the disequilibrium between pro- and anti-apoptotic BCL-2 proteins can promote cancer cell survival (Kang and Reynolds, 2009). This 
can be due to an under-expression or over-expression of the pro-apoptotic proteins and anti-apoptotic proteins, respectively, or a combination of both. In a wide variety of human cancers, both genetic and epigenetic alterations of several pro-apoptotic members of the Bcl-2 family have been reported (Galluzzi et al., 2010). Besides inactivation of pro-apoptotic BCL-2 family proteins, the presence of elevated levels of anti-apoptotic family members is an obvious mechanism of apoptosis dysregulation in cancer (Fulda, 2009). The anti-apoptotic proteins are widely over-expressed in cancer cells to overcome stress signals. Over-expression of anti-apoptotic BCL-2 family proteins is often correlated with recurrence, poor prognosis, and resistance to cancer therapeutics (Wuilleme-Toumi et al., 2005).

In addition to genetic and epigenetic alterations, there is evidence that dysregulation of MicroRNAs (miRNAs) are associated with different human cancers and miRNAs can function as oncogenes and tumor suppressors (Croce, 2009). MiRNAs are a class of non-coding RNAs that regulate post-transcriptional gene expressions and silence target mRNAs. MiRNAs have been established to act as anti-apoptotic or pro-apoptotic regulators by targeting different mRNAs involved in the apoptotic pathways, especially BCL-2 family proteins (Garofalo et al., 2010; Chen et al., 2014). For example, miR-15/16 targets the antiapoptotic factor (Bcl-2) and the loss or reduced expression of the tumor suppressor of miR-15/16 may elucidate the elevation of Bcl-2 level in some tumors (Cimmino et al., 2005; Allegra et al., 2014). Furthermore, pro-apoptotic miR-34 family members and MiR-125b down-regulate anti-apoptotic proteins and lead to decreased cellular proliferation and increased apoptosis. On the other hand, some miRNAs have oncogenic functions, including miRNA-21, the miRNA-17/92 cluster, miRNA-272/273 and miRNA-221/222, which negatively control apoptotic activity to enhance the rate of cancer cell proliferation and contribute to drug resistance (Garofalo et al., 2008; Xiao et al., 2008; Lima et al., 2011). In different types of cancer, the most constantly up-regulated miRNA is anti-apoptotic miRNA-21. It is believed that miRNA-21 can modulate apoptosis by targeting the programmed cell death 4 gene (PCD 4 gene or PDCD4), tropomyosin 1 (TPM1), and the phosphatase and tensin homologue (PTEN) (Wang and Lee, 2009). Experimental evidence shows that the utilization of anti-microRNAs or miRNA mimics may act as a potent therapeutic strategy to inhibit key molecular pathways that are present in cancer (Garofalo and Croce, 2011). Besides miRNAs, cancer cells often show altered expression patterns of diverse long noncoding RNAs (lncRNAs) in specific kinds of tumors when compared with normal cells and tissues. Therefore, their modulation (overexpression or down-regulation according to the specific lncRNA) in cancer cells often sensitizes cells to apoptotic treatments and consequently induces apoptosis, suggesting that targeting lncRNAs to modulate apoptosis in cancer cells can be utilized for cancer treatment (Rossi and Antonangeli, 2014).

Cellular-FLICE inhibitory protein (c-FLIP) is a critical negative regulator of the apoptotic pathway mediated by the death receptors Fas, TNF-R1, DR4 and DR5 (Micheau,
2003). There are three isoforms of c-FLIP protein that are derived from diverse mRNA splice variants which are transcribed under the same promoter, namely c-FLIPL, c-FLIPS, and c-FLIPR. At high expression levels, all three isoforms function at the DISC level by inhibiting the activation of procaspase- 8 and -10 , due to its structural homology with the cysteine protease (Subramaniam et al., 2013). Enhanced expression of c-FLIP (long or the short isoform) has been generally found in a wide variety of cancers (Safa and Pollok, 2011). Some reports have also demonstrated that down-regulation of c-FLIP in vitro can restore apoptosis mediated by TRAIL and CD95L. Thus, c-FLIP can be utilized as a promising target for cancer therapy, particularly if combined with other treatments, for example, TRAIL or conventional chemotherapy (Sung et al., 2010; Shirley and Micheau, 2013). In contrast to the anti-apoptotic role of c-FLIP at high levels of expression, c-FLIPL has been demonstrated to induce apoptosis at low and more physiologically relevant expression levels by recruiting at the DISC to increase caspase- 8 activation (Chang et al., 2002). In spite of the known dual function of c-FLIPL as a pro- or anti-apoptotic factor in normal tissues, c-FLIPL has usually been identified as taking action as a fundamental negative regulator of apoptosis in human cancer cells (Hassan et al., 2014). C-FLIP is a transcriptional target of a number of transcription factors. Among these transcription factors, AP-1 (c-Fos and c-Jun), CREB, SP1, and NF-kB induce c-FLIP expression. Additionally, other transcription factor binding sites have been reported that are associated with the down-regulation of c-FLIP transcription (Subramaniam et al., 2013). Activation of NF-kB by CD40 ligand or TNF $\alpha$ results in overexpression of c-FLIP and the prohibition of TNFR1, Fas- and TRAIL receptors induce apoptosis (Micheau et al., 2001; Travert et al., 2008). Similarly, growth factor stimulation or activation of several pathways, such as mitogen-activated protein kinase (MAPK), the phosphatidylinositol-3 kinase (PI3K)/Akt, can promote the expression of c-FLIP and inhibit apoptosis induced by death receptors (Micheau, 2003).

IAPs are a family of proteins that prevent both intrinsic and extrinsic apoptosis and increase cell survival during cellular stresses such as ER stress (Hamanaka et al., 2009) and loss of attachment from the extracellular matrix (Liu et al., 2006). Furthermore, IAP expression is induced by potent oncogenes, including E6 (Wu et al., 2010) and Ras (Liu et al., 2005); prosurvival signaling such as nuclear factor (NF)- $\varkappa$ B can also induce IAPs (Chu et al., 1997). In particular, well known members of this family include XIAP (X-linked IAP), surviving (BIRC5), cIAP1 (BIRC2), cIAP2 (BIRC3), Livin/MLIAP(BIRC7), Apollon (BRUCE, BIRC6), IAP-like protein 2(BIRC8), and NAIP (BIRC1) (Hawkins et al., 2001; Eckelman et al., 2006). All IAP proteins are characterized by the presence of one to three baculovirus IAP repeat (BIR) domains that mediate protein-protein interactions (Hinds et al., 1999). Inhibition of caspase activity by these proteins occurs via interaction of IAPs conserved BIR domains with active sites of caspases, which keeps the caspases away from their substrates, promoting degradation of active caspases (Wei et al., 2008). Deregulation of IAPs may 
lead to neurodegenerative disorders and cancer (Saleem et al., 2013). Direct genetic evidence has confirmed that cIAPs are proto oncogenes (Wright and Duckett, 2005), and enhanced levels of diverse members of the IAP family have been observed in many malignancies (Yang et al., 2003). Besides the oncogenic role of the IAPs, recent studies have demonstrated a tumor-suppressing role for the cIAPs in restricting NF- $x$ B activity. A number of studies have shown that mutations or translocations of cIAPs are in charge of constitutive activation of NF- $x \mathrm{~B}$ signaling in numerous cancers (Lau and Pratt, 2012). These studies reveal that both over-expression and loss of cIAPs can promote metastasis and tumor invasion (Lau and Pratt, 2012; Tchoghandjian et al., 2013).

Due to the importance of caspases in the initiation and execution of apoptosis, it is logical to consider that impairment in caspase function or low levels of caspases may result in a reduction of apoptosis and carcinogenesis. Down-regulation of different caspases has been observed in diverse cancers; for example, down-regulation of caspase-9 can leads to colorectal cancer and correlates with poor clinical outcomes. In addition, Devarajan et al. observed decreased levels of caspase 3 in ovarian, breast, and cervical cancers and it is established that restoring caspase-3 expression in breast cancer cells (MCF7) leads to increased sensitivity of these cells to undergo apoptosis in response to anticancer drugs or other apoptotic stimuli of (Devarajan et al., 2002). Notably, there is some evidence that has shown the down-regulation of more than one caspase, which contributes to tumor development (Fong et al., 2006).

\section{Targeting Apoptosis in Cancer Treatment}

In recent years, a lot of attention has been paid to developing diverse promising experimental anti-cancer drugs that can modulate apoptotic pathways. Due to apoptosis being a double-edged sword, researchers target every defect or abnormality along the apoptotic pathways to restore the apoptotic signaling pathways and eliminate cancer cells (Table 1).

\section{Targeting anti-apoptotic Bcl-2 family members}

As mentioned above, over-expression of prosurvival BCL-2 family members are associated with aggressive cancer and/or chemoresistance which mark these proteins as highly promising therapeutic targets to develop pharmacological manipulation of cell death through down-regulating anti-apoptotic BCL-2 family members. Recent studies showed the inhibition of prosurvival BCL2 family members by small interfering RNAs (siRNAs) could result in the induction of cells apoptosis and subsequently a reduction in tumor growth. For example, Specific down-regulation of Mcl-1 by siRNA induced significant apoptosis in leukemia cells in vitro (Karami et al., 2014). Furthermore, several microRNAs have been identified that regulate Bcl-2 expression. For instance, Sing et al. demonstrated that miR-195, miR-24-2, and miR-365-2 act as negative regulators of Bcl-2 via direct binding to the 3'-UTR of the BCL2 gene, which shows the therapeutic potential of these miRNAs (Singh and Saini, 2012). In addition, miRNA-15a and miRNA-16-1 have been reported to play an important role in the targeting

Table 1. Preclinical and Clinical Trials of Some Novel Therapeutic Agents that Target Apoptosis in Cancer Cells

\begin{tabular}{|c|c|c|c|c|}
\hline Agents & $\begin{array}{l}\text { Target/ } \\
\text { mecha- } \\
\text { nism }\end{array}$ & Phase & Target disease & $\begin{array}{l}\text { References/ClinicalTrials.gov } \\
\text { Identifier \& sponser }\end{array}$ \\
\hline \multicolumn{5}{|c|}{ I) Targeting Anti-apoptotic Bcl-2 Family Members using Bcl-2 antisense } \\
\hline $\begin{array}{l}\text { Oblimersen } \\
\text { Sodium } \\
\text { (G3139, Ge- } \\
\text { nasense (trial } \\
\text { name)) }\end{array}$ & $\begin{array}{l}\text { Inhibits } \\
\text { bcl-2 }\end{array}$ & $\begin{array}{l}\text { Phase I } \\
\text { Phase I/II } \\
\text { Phase I/II } \\
\text { Phase I/II } \\
\text { Phase II } \\
\text { Phase II } \\
\text { Phase II } \\
\text { Phase II } \\
\text { Phase II } \\
\text { Phase III } \\
\text { Phase III } \\
\text { Phase III }\end{array}$ & $\begin{array}{l}\text {-Acute Myeloid Leukemia (combined with } \\
\text { Cytarabine, and Daunorubicin) } \\
\text {-Advanced Colorectal Cancer ( combined with } \\
\text { Chemotherapy) } \\
\text {-Advanced Esophageal, Gastro-Esophageal } \\
\text { Junction and Gastric Cancer( combined with } \\
\text { Cisplatin and Fluorouracil) } \\
\text {-Advanced Breast Cancer ( combined with } \\
\text { Doxorubicin and Docetaxel) } \\
\text {-Merkel Cell Carcinoma } \\
\text {-Chronic Myelogenous Leukemia(combined } \\
\text { with Imatinib Mesylate) } \\
\text {-B-cell-Hodgkin lymphoma ( combined with } \\
\text { Rituximab) } \\
\text {-Chronic Myelogenous Leukemia (combined } \\
\text { with Imatinib Mesylate) } \\
\text {-Small cell Lung Cancer ( combined with carbo- } \\
\text { platin/etoposide) } \\
\text {-Multiple Myeloma and plasma cell Neoplasm } \\
\text { (with or without dexamethasone) } \\
\text {-Chronic lymphocytic leukemia (CLL) (com- } \\
\text { bined with Fludarabine and Cyclophosphamide) } \\
\text {-Myeloma(plus dacarbazine) }\end{array}$ & $\begin{array}{l}\text { NTC00039117* / (NCI**) } \\
\text { NTC00055822/ (NTC) } \\
\text { NTC00064259/ (NTC) } \\
\text { NCT00063934/ (NTC) } \\
\text { NCT00079131/ (NCT) } \\
\text { NCT00049192/ (NCT) } \\
\text { NCT00054639/ (NCT) } \\
\text { NCT00049192/ (NTC) } \\
\text { NCT00042978/ (NTC) } \\
\text { NCT00017602/ (Genta Incor- } \\
\text { porated) } \\
\text { NCT00024440/ (Genta Incor- } \\
\text { porated) } \\
\text { NCT00016263 } \\
\& \text { NCT00518895/ (Genta } \\
\text { Incorporated) }\end{array}$ \\
\hline
\end{tabular}


Table 1 (cont). Preclinical and Clinical Trials of Therapeutic Agents that Target Apoptosis in Cancer Cells

\begin{tabular}{|c|c|c|c|c|}
\hline \multicolumn{5}{|c|}{ II) Small molecule inhibitors of BCL-2 proteins } \\
\hline \multicolumn{5}{|c|}{ a) Molecules that affect gene or protein expression: } \\
\hline \multicolumn{5}{|c|}{$\begin{array}{l}\text { Drugs that modulate the activity of retinoic acid receptors (RAR), retinoid X receptors (RXR), PPAR, vitamin D receptors } \\
\text { (VDR): }\end{array}$} \\
\hline $\begin{array}{l}\text { Troglitazone } \\
\Delta 2 \text {-TG }\end{array}$ & $\begin{array}{l}\text { Inhibit the anti-apoptotic func- } \\
\text { tions of Bcl-xL and Bcl-2 }\end{array}$ & Phase II & -Advanced prostate cancer & $\begin{array}{l}\text { (Grillier-Vuissoz and } \\
\text { Isabelle, 2012) }\end{array}$ \\
\hline \multicolumn{5}{|c|}{ Histon deacetylase inhibitors: } \\
\hline $\begin{array}{l}\text { Sodium } \\
\text { butyrate }\end{array}$ & $\begin{array}{l}\text { Downregulate the expression of } \\
\text { Bcl-2 }\end{array}$ & $\begin{array}{l}\text { Preclinical } \\
\text { Preclinical } \\
\text { preclinical }\end{array}$ & $\begin{array}{l}\text {-Lymphoma } \\
\text {-Prostate cancer } \\
\text {-gastric cancer cells }\end{array}$ & $\begin{array}{l}\text { (Duan et al., 2005) } \\
\text { (Qiu et al., 2012) } \\
\text { (Shin et al., 2012a) }\end{array}$ \\
\hline \multicolumn{5}{|c|}{ Synthetic cytotoxic retinoid: } \\
\hline Fenretinide & $\begin{array}{l}\text { Caspase } 9 \text { activation , Bcl-2 and } \\
\text { Mcl- } 1 \text { down-regulation and not } \\
\text { effect on Bax expression }\end{array}$ & $\begin{array}{l}\text { Preclinical } \\
\text { Preclinical }\end{array}$ & $\begin{array}{l}\text {-Rhabdomysarcoma } \\
\text {-Ovarian carcinoma }\end{array}$ & $\begin{array}{l}\text { (Herrero Martin et al., } \\
\text { 2013) } \\
\text { (Tiberio et al., 2010) }\end{array}$ \\
\hline \multicolumn{5}{|c|}{ Cyclin-dependent kinase inhibitor: } \\
\hline $\begin{array}{l}\text { Flavopiridol } \\
\text { (Alvoidib) }\end{array}$ & $\begin{array}{l}\text { Down-regulation of Mcl-1 and } \\
\text { Bcl-xL, Bid cleavage, and mito- } \\
\text { chondrial translocation of Bax }\end{array}$ & $\begin{array}{l}\text { Preclinical } \\
\text { Preclinical } \\
\text { Preclinical } \\
\text { Phase I/II } \\
\text { Phase II } \\
\text { Phase II } \\
\text { Phase II } \\
\text { Phase II }\end{array}$ & $\begin{array}{l}\text {-B-cell chronic lymphocytic } \\
\text {-Myeloma (combined with } \\
\text { HA14-1) } \\
\text {-Acute myelogenous leukemia } \\
\text {-Small cell lung cancer (com- } \\
\text { bination with Topotecan) } \\
\text {-Metastatic, or Primary Adreno- } \\
\text { cortical cancer } \\
\text {-Glioblastoma Multiforme } \\
\text {-Non-Small Cell Lung Cancer ( } \\
\text { combined with Docetaxel) } \\
\text {-Advanced Laryngeal Cancer ( } \\
\text { combined with Chemotherapy) }\end{array}$ & $\begin{array}{l}\text { (Kitada et al., 2000) } \\
\text { (Pei et al., 2004) } \\
\text { (Bose and Grant, 2013) } \\
\text { NCT00397293 } \\
\text { (Ascenta therapeutics) } \\
\text { NCT00848016 (NCI) } \\
\text { NCT00540722 (NCI) } \\
\text { NCT00544960 (Ascenta } \\
\text { therapeutics) } \\
\text { NCT01633541 } \\
\text { Francis(Frank)Worden }\end{array}$ \\
\hline \multicolumn{5}{|c|}{ b) Molecules acting on proteins themselves } \\
\hline \multicolumn{5}{|c|}{ BH-3 domain Inhibitors } \\
\hline $\begin{array}{l}\text { Gossypol/ } \\
\text { AT-101 }\end{array}$ & $\begin{array}{l}\text { Inhibitor of Bcl-2 family proteins } \\
\text { including Bcl-2, Bcl-xL, Mcl- } \\
\text { 1 and Bcl-w }\end{array}$ & $\begin{array}{l}\text { Phase II } \\
\text { Phase II }\end{array}$ & $\begin{array}{l}\text {-Small Cell Lung Cancer } \\
\text {-Non-Small Cell Lung Cancer }\end{array}$ & $\begin{array}{l}\text { NCT00773955 } \\
\text { NCT00544960 } \\
\text { (Ascenta Therapeutics) }\end{array}$ \\
\hline $\begin{array}{l}\text { Obatoclax } \\
\text { Mesylate } \\
\text { (GX15- } \\
\text { 070MS) }\end{array}$ & $\begin{array}{l}\text { antagonizes Bcl-2, Bcl-XL, } \\
\text { Bcl-w and Mcl-1(pan-BCL-2 } \\
\text { antagonist) }\end{array}$ & $\begin{array}{l}\text { Phase I } \\
\text { Phase I } \\
\text { Phase I } \\
\text { Phase I } \\
\text { Phase I/II } \\
\text { Phase II } \\
\text { Phase II }\end{array}$ & $\begin{array}{l}\text {-Chronic Lymphocytic Leuke- } \\
\text { mia (CLL) } \\
\text {-Non-Hodgkin Lymphoma } \\
\text { (combined with Bortezomib) } \\
\text {-Hematological Malignancies } \\
\text {-Solid Tumors, Lymphoma, } \\
\text { or Leukemia (combined with } \\
\text { Vincristine Sulfate, Doxorubicin } \\
\text { Hydrochloride, and Dexrazox- } \\
\text { ane Hydrochloride) } \\
\text {-Non-Small Cell Lung Cancer } \\
\text { (combined with Docetaxel) } \\
\text {-Acute Myeloid Leukemia } \\
\text { (AML) } \\
\text {-Hodgkin's Lymphoma }\end{array}$ & $\begin{array}{l}\text { NCT00600964 } \\
(\text { Gemin X) } \\
\text { NCT00538187 } \\
\text { (NCI) } \\
\text { NCT00438178 } \\
(\text { Gemin X) } \\
\text { NCT00933985 } \\
\text { (NCI) } \\
\\
\text { NCT00405951 } \\
\text { (Gemin X) } \\
\text { NCT00684918 } \\
\text { (Gemin X) } \\
\text { NCT00359892 } \\
(\text { Gemin X) }\end{array}$ \\
\hline ABT-737 & $\begin{array}{l}\text { Inhibits Bcl-2, Bcl-xL, and } \\
\text { Bcl-W }\end{array}$ & $\begin{array}{l}\text { preclinical } \\
\text { Phase I/II } \\
\text { Phase I/II } \\
\text { Phase II }\end{array}$ & $\begin{array}{l}\text {-Leukemia lymphoma, my- } \\
\text { eloma, glioma and small cell } \\
\text { lung cancer cells } \\
\text {-Metastatic breast cancer } \\
\text {-Castrate-resistant prostate } \\
\text { cancer(CRPC) } \\
\text {-Ovarian Tumors (association of } \\
\text { platinum) }\end{array}$ & $\begin{array}{l}\text { (Oltersdorf et al., 2005; } \\
\text { Chauhan et al., 2007; Tru- } \\
\text { del et al., 2007; Tagscherer } \\
\text { et al., 2008) } \\
\text { (Van Poznak et al., 2001) } \\
\text { (Liu et al., 2009) } \\
\text { NCT01440504 } \\
\text { (Centre Francois Baclesse) }\end{array}$ \\
\hline
\end{tabular}


Table 1 (cont). Preclinical and Clinical Trials of Therapeutic Agents that Target Apoptosis in Cancer Cells

\begin{tabular}{|c|c|c|c|c|}
\hline $\begin{array}{l}\text { ABT-263 or } \\
\text { navitoclax }\end{array}$ & $\begin{array}{l}\text { Inhibits } \mathrm{Bcl}-2, \mathrm{Bcl}-\mathrm{XL} \text {, and } \mathrm{Bcl}- \\
\mathrm{w} \text { but not for MCL- } 1 \text { or A1 }\end{array}$ & $\begin{array}{l}\text { Phase I } \\
\text { PhaseI } \\
\text { Phase II } \\
\text { Phase II }\end{array}$ & $\begin{array}{l}\text {-Solid Tumors (combined with } \\
\text { Paclitaxel) } \\
\text {-Solid Tumors (combined with } \\
\text { Gemzar (Gemcitabine)) } \\
\text {-Chronic Lymphocytic Leuke- } \\
\text { mia (CLL) } \\
\text {-Small Cell Lung Cancer }\end{array}$ & $\begin{array}{l}\text { NCT00891605 } \\
\text { (Abbott) } \\
\text { NCT00887757 } \\
\text { (Abbott) } \\
\text { NCT01557777 } \\
\text { AbbVie (prior sponsor, } \\
\text { Abbott)(Rudin et al., } \\
\text { 2012) }\end{array}$ \\
\hline \multirow[t]{2}{*}{$\begin{array}{l}\text { ABT-199/ } \\
\text { GDC-0199 }\end{array}$} & $\begin{array}{l}\text { Selective inhibitor of Bcl-2 } \\
\text { proteins }\end{array}$ & $\begin{array}{l}\text { Phase I } \\
\text { Phase I }\end{array}$ & $\begin{array}{l}\text {-Human multiple myeloma } \\
\text {-Relapsed or Refractory } \\
\text { Chronic Lymphocytic Leuke- } \\
\text { mia (CLL) and Non-Hodgkin's } \\
\text { Lymphoma }\end{array}$ & $\begin{array}{l}\text { (Touzeau et al., 2014) } \\
\text { (Roberts; Matthew S. } \\
\text { Davids, 2013) } \\
\text { NCT01328626 } \\
\text { AbbVie (prior sponsor, } \\
\text { Abbott) }\end{array}$ \\
\hline & & Preclinical & $\begin{array}{l}\text {-Estrogen receptor (ER)-posi- } \\
\text { tive breast cancer }\end{array}$ & (Vaillant et al., 2013) \\
\hline $\begin{array}{l}\text { VDAC1- } \\
\text { based cell- } \\
\text { penetrating } \\
\text { peptides }\end{array}$ & $\begin{array}{l}\text { Targeted } \mathrm{HK}^{3}, \mathrm{Bcl}-2 \text { and } \mathrm{Bcl}- \\
\mathrm{xL} \text { to ihibit the interaction of } \\
\text { VDAC } 1 \text { and the anti-apoptotic } \\
\text { proteins }\end{array}$ & Phase I & $\begin{array}{l}\text {-B-cell chronic lymphocytic } \\
\text { leukemia (CLL) }\end{array}$ & (Prezma et al., 2013) \\
\hline
\end{tabular}

of prosurvival Bcl-2 proteins in chronic lymphocytic leukemia (CLL) (Calin et al., 2008).

A number of drugs directed at inhibiting anti-apoptotic BCL-2 family proteins have been developed, with some showing great promise in clinical settings (Weyhenmeyer et al., 2012; Roy et al., 2014). Two strategies are recommended to block Bcl-2 and Bcl-xL, including I) application of Bcl-2 antisense, and II) application of small molecule inhibitors of the Bcl-2 family of proteins.

Bcl2 antisense: Bcl2 antisense down-regulates Bcl2 proteins by target the corresponding mRNA. These include Oblimersen sodium (G3139, Genasense), an 18-antisense oligonucleotide that is the first agent targeting Bcl-2 mRNA to enter clinical trials. The apoptotic effect of this compound happens through an increase in Bax and PARP, releasing cytochrome c and Smac/ DIABLO from mitochondria, which can activate caspases (Emi et al., 2005). Reduction of Bcl-2 expression by Oblimersen sodium in preclinical studies had cytotoxic and cytostatic effects on breast (Emi et al., 2005), ovarian (Bartholomeusz et al., 2005), prostate (Chi et al., 2001; Leonetti et al., 2007), melanoma (De Cesare et al., 2005), NSCLC (Hu et al., 2004), bladder (Duggan et al., 2001), and gastric cancers cells (Wacheck et al., 2001). This compound is entering phase I to III human clinical trials (O'Brien, 2009).Also, most clinical trials combine the antisense agent with cytotoxic anticancer drugs for in order to promote the drug sensitivity of different cancer cells (Table 1).

Small molecule inhibitors of BCL-2 proteins: Small molecule inhibitors of BCL-2 proteins are divided in two groups, 1) molecules that affect gene or protein expression, and 2) molecules acting on proteins themselves (Table 1).

i) Molecules that affect gene or protein expression: There are some components that represent potentially "druggable" modulators of Bcl-2 and Bcl-xL genes, such as some members of the steroid/retinoid superfamily of ligand-activated transcription factors (SRTFs). Some members of the SRTF superfamily that can downregulate the expression of Bcl- 2 or Bcl-xL are some small molecule drugs that modulate the activity of retinoic acid receptors (RAR), retinoid X receptors (RXR), PPAR, and vitamin $\mathrm{D}$ receptors (VDR) in specific types of cancer and leukemia cells (Hassan et al., 2014). For instance, Troglitazoneor $\Delta 2-T G$, a potent PPAR agonist, can inhibit the anti-apoptotic functions of Bcl-xL and Bcl-2 and cause caspase-dependent apoptosis via caspase-9 activation (Shiau et al., 2005; Grillier-Vuissoz and Isabelle, 2012). In addition, there is evidence that pretreatment of PC-3 cells with the pan-caspase inhibitor Z-VAD-FMK protects cells from troglitazone- and $\Delta 2$-TG-activated apoptosis, which verifies the involvement of caspase activation in apoptotic death (Shiau et al., 2005). Furthermore, histone deacetylase inhibitors (e.g., sodium butyrate, trichostatin A ) (Duan et al., 2005), synthetic cytotoxic retinoids (e.g., Fenretinide) in a ROS-independent manner(Tiberio et al., 2010; Herrero Martin et al., 2013), cyclin-dependent kinase inhibitors (e.g., Flavopiridol ) (Kitada et al., 2000; Pei et al., 2004; Bose and Grant, 2013), Deubiquitinase inhibitors (e.g., WP1130) (Sun et al., 2011) are several other molecules that affect gene or protein expression by down-regulating RNA expression in various cancer cells.

ii) Molecules acting on proteins themselves: These molecules directly bind with anti-apoptotic Bcl-2 proteins at their $\mathrm{BH} 3$-binding groove and mimic the action of BH3 proteins (de Almagro and Vucic, 2012). These small molecules, all less than 750 daltons (Azmi and Mohammad, 2009), demonstrate targeting of the different anti-apoptotic members of the Bcl-2- family, such as Bcl-2, Bcl-xL, Bcl-W, Mcl-1, Bcl-B, and Bfl1 , in terms of balancing antitumor efficacy. The most prominent examples of these agents include gossypol, Obatoclax (GX15-070), ABT-737, and ABT-263 or navitoclax (Oltersdorf et al., 2005; Kang and Reynolds, 
Table 1 (cont). Preclinical and Clinical Trials of Therapeutic Agents that Target Apoptosis in Cancer Cells

\begin{tabular}{|c|c|c|c|c|}
\hline \multicolumn{5}{|c|}{ III) Strategies that target p53 to activate apoptosis } \\
\hline \multicolumn{5}{|c|}{ a) Small-molecule HDM2 inhibitors: } \\
\hline $\begin{array}{l}\text { R7112(Nultlin-3, } \\
\text { analogues of } \\
\text { cis imidazoline) } \\
\text { JNJ-26854165 } \\
\text { (a tryptamine } \\
\text { derivative) }\end{array}$ & $\begin{array}{l}\text { Preventing MDM2- } \\
\text { P53 interaction } \\
\text { Prevention of } \\
\text { MDM2-P53 inter- } \\
\text { action }\end{array}$ & Phase I & $\begin{array}{l}\text {-Advanced solid Tumors } \\
\text {-Advanced Stage or Refractory Solid } \\
\text { Tumors }\end{array}$ & $\begin{array}{l}\text { NCT00559533 } \\
\text { ( Hoffmann-La Roche) } \\
\text { NCT00676910 } \\
\text { (Johnson \& Johnson Pharma- } \\
\text { ceutical Research \& Develop- } \\
\text { ment, L.L.C) }\end{array}$ \\
\hline \multicolumn{5}{|c|}{ b) Small molecules which restore the mutated p53 to wild-type p53: } \\
\hline $\begin{array}{l}\text { MIRA-3 } \\
\text { PK083 } \\
\text { PRIMA-1 } \\
\text { APR-246 }\end{array}$ & $\begin{array}{l}\text { Reactivates mutant } \\
\text { P53 and inhibits } \\
\text { ubiquitination of } \\
\text { P53 by HDM2 } \\
\text { Reactivates mutant } \\
\text { p53 } \\
\text { Reactivation of } \\
\text { Y220C mutant p53 } \\
\text { Reactivates mutant } \\
\text { p53 } \\
\text { Reactivates mutant } \\
\text { p53 }\end{array}$ & $\begin{array}{l}\text { Preclinical } \\
\text { Preclinical } \\
\text { Preclinical } \\
\text { Phase I }\end{array}$ & $\begin{array}{l}\text {-WiDr, DLD-1, KLE, H322, MCF7, } \\
\text { SJSA, WS-1, AND MB-468 Cancer } \\
\text { cells } \\
\text {-Tumor cells } \\
\text {-Tumor cells } \\
\text {-Tumor cells (combined treatment } \\
\text { with cisplatin) } \\
\text {-Malignancies or hormone-refractory } \\
\text { prostate cancer }\end{array}$ & $\begin{array}{l}\text { (Demma et al., 2010) } \\
\text { (Bykov et al., 2005a) } \\
\text { (Boeckler et al.,2008) } \\
\text { (Bykov et al., 2005b) } \\
\text { (Lehmann et al., 2012) }\end{array}$ \\
\hline \multicolumn{5}{|l|}{ c) p53 vaccines: } \\
\hline $\begin{array}{l}\text { Peptide-based } \\
\text { vaccines } \\
\text { Dendritic-cell } \\
\text { based vaccines } \\
\text { Recombinant } \\
\text { Virus }\end{array}$ & $\begin{array}{l}\text { Facilitate the } \\
\text { induction of } \\
\text { antitumor immune } \\
\text { responses, particu- } \\
\text { larly } \\
\text { antitumor CTL }\end{array}$ & $\begin{array}{l}\text { Phase I/II } \\
\text { Phase II } \\
\text { Phase II } \\
\text { Phase I/II } \\
\text { Phase I/II } \\
\text { Phase I/II } \\
\text { Phase I }\end{array}$ & $\begin{array}{l}\text {-Colorectal cancer } \\
\text {-Ovarian cancer } \\
\text {-Advanced (Breast, Cervical, Colo- } \\
\text { rectal, Lung, Ovarian, Pancreatic) } \\
\text {-Breast Cancer } \\
\text {-Colorectal Cancer } \\
\text {-Small cell lung cancer } \\
\text {-Brain and Central Nervous System } \\
\text { Tumors }\end{array}$ & $\begin{array}{l}\text { (Speetjens et al., 2009) } \\
\text { (Leffers et al., 2009) } \\
\text { NCT00019084 } \\
\text { (Svane et al., 2004; 2007) } \\
\text { (Menon et al., 2003) } \\
\text { (Atencio et al., 2006) } \\
\text { (Antonia et al., 2006) } \\
\text { NCT00004080 } \\
\text { (NCI) }\end{array}$ \\
\hline \multicolumn{5}{|c|}{ IV) Antibodies which target TRAIL-receptors } \\
\hline Dulanermin & $\begin{array}{l}\text { Targets TRAIL-R1 } \\
\text { and TRAIL-R2 }\end{array}$ & Phase I/II & $\begin{array}{l}\text {-Non-Hodgkin's Lymphoma } \\
\text { (Combined with Rituximab) }\end{array}$ & $\begin{array}{l}\text { NCT00400764 } \\
\text { (Genentech, Inc) }\end{array}$ \\
\hline $\begin{array}{l}\text { Mapatumumab } \\
\text { (HGS } \\
\text { ETR1,TRM-1) }\end{array}$ & Targets TRAIL-R1 & Phase II & $\begin{array}{l}\text {-Multiple Myeloma } \\
\text { (combined with Bortezomib) }\end{array}$ & $\begin{array}{l}\text { NCT00315757 (Human Ge- } \\
\text { nome Sciences Inc.) }\end{array}$ \\
\hline $\begin{array}{l}\text { Lexatumumab } \\
\text { (HGS-ETR2) }\end{array}$ & Targets TRAIL-R2 & Phase I & -Metastatic Tumors & $\begin{array}{l}\text { NCT00428272 } \\
(\mathrm{NCI})\end{array}$ \\
\hline $\begin{array}{l}\text { Conatumumab } \\
\text { (AMG 655) }\end{array}$ & Targets TRAIL-R2 & Phase I/II & $\begin{array}{l}\text {-Colon Cancer Colorectal Cancer } \\
\text { Rectal Cancer Metastatic Colorectal } \\
\text { Cancer Oncology } \\
\text { (combined with panitumumab) }\end{array}$ & $\begin{array}{l}\text { NCT00630786 } \\
\text { (Agmen) }\end{array}$ \\
\hline Drozitumab & Targets TRAIL-R2 & Phase Ib & $\begin{array}{l}\text {-Metastatic colorectal cancer (mCRC) } \\
\text { (combined with Cetuximab }+ \text { irinote- } \\
\text { can or FOLFIRI } \pm \text { bevacizumab) }\end{array}$ & (Baron, 2011) \\
\hline Tigatuzumab & Targets TRAIL-R2 & Phase II & $\begin{array}{l}\text {-Breast cancer (combined with Ab- } \\
\text { raxane) }\end{array}$ & $\begin{array}{l}\text { NCT01307891 (University of } \\
\text { Alabama at Birmingham) }\end{array}$ \\
\hline LBY135 & Targets TRAIL-R2 & Phase I/II & $\begin{array}{l}\text {-Solid tumor (with or without } \\
\text { capecitabine) }\end{array}$ & (Sharma et al., 2014) \\
\hline
\end{tabular}

*1http://clinicaltrials.gov/; ${ }^{2}$ National Cancer Institute; ${ }^{3}$ hexokinase 
2009; Albershardt et al., 2011). ABT-737 is a pan-BCL-2 inhibitor which mimics the $\mathrm{BH} 3$ domain of BAD, binds selectively to BCL-2, BCL-XL and BCL-W, and exhibits remarkable antitumor activity in human cancers (Oltersdorf et al., 2005). ABT-199/GDC-0199, a $\mathrm{BH} 3$-mimetic, is a selective inhibitor of BCL-2 proteins through restoring the communication system that tells cancer cells to self-destruct. This compound is currently in clinical trials for the treatment of CLL; Non-Hodgkin's Lymphoma (NHL), and multiple myeloma, breast cancer (Roberts; Matthew S. Davids, 2013; Vaillant et al., 2013; Touzeau et al., 2014). However, the safety and efficacy of ABT-199/GDC-0199 have not been established.

Voltage-dependent anion channel (VDAC, also known as porin) which is located in the mitochondrial outer membrane, directly contributes to MOMP and intercedes with cytochrome $\mathrm{c}$ release, either by oligomer formation (Shoshan-Barmatz et al., 2010) or by the formation of a large pore comprising VDAC and Bax/Bak (MartinezCaballero et al., 2009). Tajeddine N. et al. reported that knockdown of the VDAC1 was able to inhibit cell death induced by cisplatin (Tajeddine et al., 2008). In addition, Arbel N. et al have demonstrated that direct interaction of anti-apoptotic Bcl-2 and Bcl-xL with VDAC results in decreased channel conductance and causes anti-apoptotic actions (Arbel et al., 2012). Thus, searching for compounds that block the binding of VDAC1 and prosurvival/antiapoptotic hexokinase (HK) and $\mathrm{Bcl}-2$ family proteins may be promising targets for anticancer drug research (Shoshan-Barmatz and Mizrachi, 2012). Recently, Prezma T. et al. have designed VDAC1-based cell-penetrating peptides which target $\mathrm{HK}, \mathrm{Bcl}-2$ and $\mathrm{Bcl}-\mathrm{xL}$ to inhibit the interaction of VDAC1 and the anti-apoptotic proteins in B-cell CLL (Prezma et al., 2013).

\section{Targeting $p 53$}

One of the most essential roles of p53 is its ability to activate apoptosis through both transcription-dependent and transcription-independent ways (Figure 1) (Chi, 2014). The disturbance of this process can cause tumor progression and chemoresistance. There are different strategies that target p53 to activate apoptosis, such as

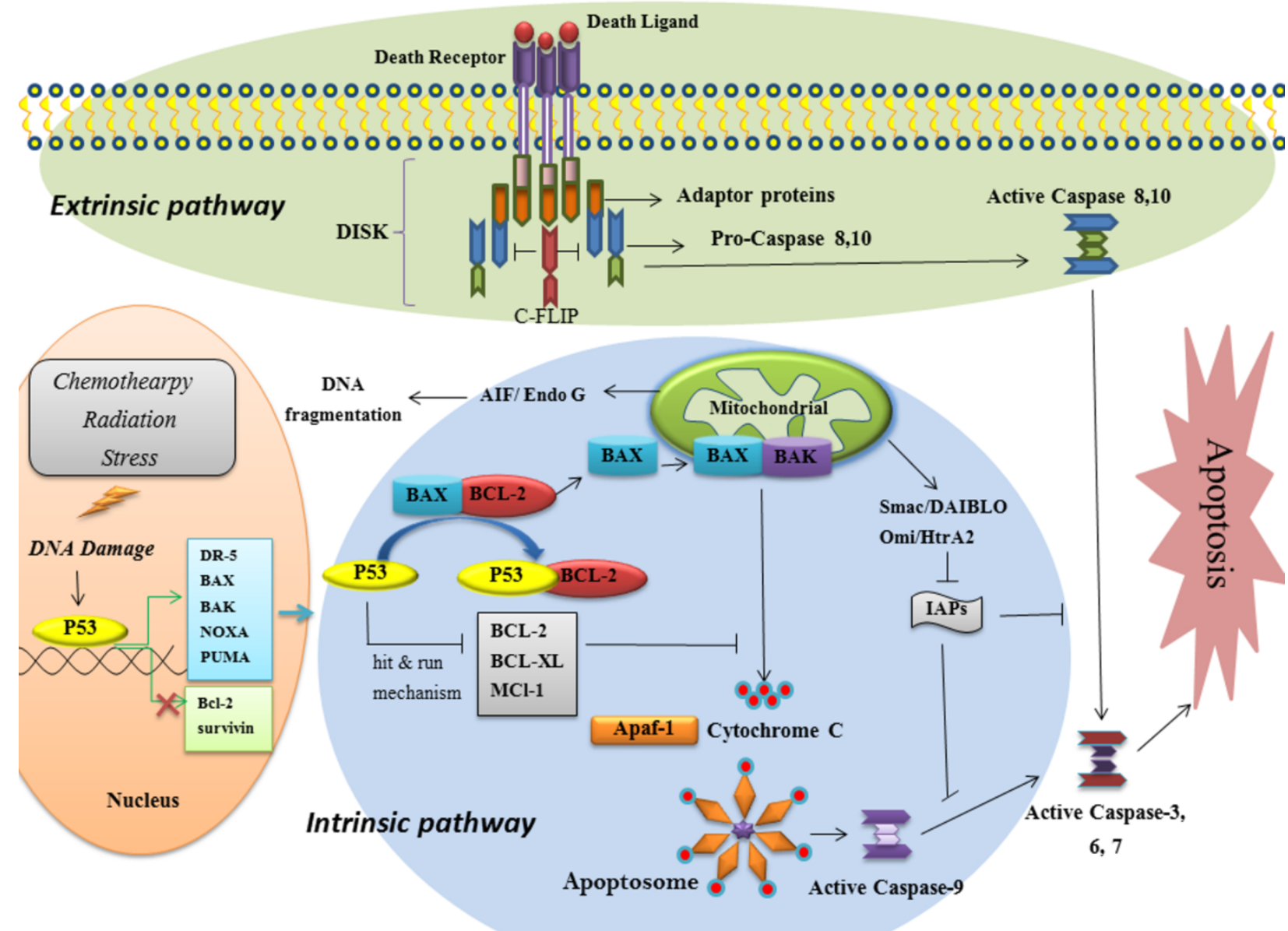

Figure 1. Schematic Diagram of the Intrinsic, Extrinsic Pathways of Apoptosis. Apoptosis is executed via two central apoptotic pathways, the extrinsic and the intrinsic pathways. Both apoptotic pathways converge on the same terminal or execution pathway. The extrinsic pathway begins with the attachment of extracellular ligands to the extracellular domain of transmembrane receptors, whereas mitochondrial apoptosis is initiated by several intracellular stimuli. Initiator caspase of both pathways (caspase 8 and 9,10 ) can catalyse the proteolytic maturation of effector caspases (such as caspase 3,6,7), which lead to initiation of a caspase cascade and finally result in demolition of the cell. DNA damage triggers apoptosis by activation of the tumor-suppressor protein p53, which induces the transcription of DR-5, BAX, BAK, NOXA, PUMA and also can inhibits the transcription of anti-apoptotic genes such as Bcl-2 and survivin. The cytoplasmic interaction of $\mathrm{p} 53$ with the anti-apoptotic Bcl-2 family proteins in the mitochondria induces the release of apoptogenic factors such as cytochrome $\mathrm{c}$ from the mitochondrial outer membrane. In addition, p53 can interact directly with Bak and/or Bax and activate these through a "hit and run" mechanism that prompts the permeabilization of the outer mitochondrial membrane 
targeting p53 family proteins, inhibition of p53-MDM2 interaction, restoring mutated $\mathrm{p} 53$ back to their wild-type functions, eliminating mutant $\mathrm{p} 53$, creating p53-based vaccines, and gene therapy to restore p53 function (Table 1) (Hong et al., 2014). The function of p53 is negatively regulated by oncoproteins such as MDM2 (known as HDM2 in humans) and MDMX through an interaction with the p53 transactivation domain (p53TAD) (Oliner et al., 1993). Therefore, one of the main targets for cancer therapy is inhibition of the p53TAD-MDM2/MDMX interaction via the small molecule MDM2 antagonist that stabilizes p53 by blocking its interaction with MDM2 and selectively induces senescence in cancer cells(IancuRubin et al., 2014). Some of these small molecule MDM2 inhibitors such as R7112 (Nutlin-3, analogues of cisimidazoline) and JNJ-26854165 (a tryptamine derivative) are currently under clinical assessment in phase I studies (Tabernero et al., 2011; Shaomeng Wang et al., 2012; Sosin et al., 2012). In addition, Jae-sun Shin et al. have shown that a 5 53TAD-mimetic MDM2 antagonist, R7112, can directly interact with $\mathrm{BH} 3$ peptide-binding grooves of diverse anti-apoptotic Bcl-2 family proteins such as Bcl-2, Bcl-xL, Mcl-1 and Bcl-w in an analogous mode (Shin et al., 2012b; Shin et al., 2014).

Another class of drugs restores mutated p53 to wildtype p53 through binding to and stabilization of mutant p53, such as SCH529074, MIRA-3, PK083 (Y220C mutant p53), PRIMA-1 and its analog APR-246 ((PRIMA1MET) (Bykov and Wiman, 2014). PK083 (the carbazole derivative) interacts with a small cleft in the destabilized p53 mutant and raises the melting temperature of Y220C mutant p53 and restores its function (Boeckler et al., 2008).

In addition, numerous clinical trials have been performed using different kinds of $\mathrm{p} 53$ vaccines including I) short and long peptide-based vaccines, II) dendritic cellbased vaccines, and III) recombinant replication-defective adenoviral vectors with human wild-type p53 (Kuball et al., 2002; Svane et al., 2004; Vermeij et al., 2011).

One attractive p53 gene-based strategy is the utilization of a genetically engineered oncolytic adenovirus. One p53expressing adenovirus which is used for the treatment of tumors lacking p53 function is ONYX-015(d11520), in which the E1B-55 kDa gene has been removed. ONYX015 selectively replicates and lyses tumor cells deficient in p53 and leaves normal cells unaffected (Nemunaitis et al., 2000). Therefore it can be used for the treatment of tumors lacking p53 function (Nemunaitis et al., 2000; Cohen and Rudin, 2001).Over-expression of the wild-type p53 gene has been demonstrated to sensitize tumor cells of colorectal cancers, prostate cancers, glioma, and head and neck to ionizing radiation(P:, 2001). Moreover, Mirza A. et al. have shown that the expression of wild-type p53 was associated with strong repression of the survivin expression at both mRNA and protein levels in various cell types (Mirza et al., 2002).

\section{Targeting the extrinsic pathway}

Besides disequilibrium between pro- and antiapoptotic BCL-2 proteins which leads to the evasion of the intrinsic pathway of apoptosis, some abnormalities in the death signaling pathways have been reported to have an important place in the evasion of the extrinsic pathway of apoptosis. For example, changes in death ligand and death receptor expression and abnormal expression of decoy receptors have been described in various cancers (Reesink-Peters et al., 2005). Tumor necrosis factor-related apoptosis-inducing ligand (TRAIL) induces apoptosis in cancer cell lines. TRAIL-receptor 1 (TRAIL-R1 or death receptor 4) and TRAIL-receptor 2(TRAIL-R2 or death receptor 5) are the main agonistic receptors for TRAIL. TRAIL appears to have minimal activity in cancer cells against most normal cell types but TRAIL-R1 and TRAIL-R2 expression increases in a variety of solid tumors (Spierings et al., 2004). There is some evidence that has shown pro-apoptotic receptor agonists (PARAs), such as antibodies against TRAILreceptors and recombinant human (rh) TRAIL antibodies, can induce apoptosis in a variety of tumor types and can be utilized as an effective anti-cancer strategy (Ashkenazi et al., 1999; Ichikawa et al., 2001).

Some of these antibodies which target TRAIL-receptors include Dulanermin (a recombinant human TRAIL antibody targeting both TRAIL-R1 and TRAIL-R2), Mapatumumab (a monoclonal agonistic antibody targeting TRAIL-R1), Lexatumumab, Conatumumab, Drozitumab, tigatuzumab, and LBY135 (a monoclonal agonistic antibody targeting TRAIL-R2) (Table 1) (Khan et al., 2014). Mapatumumab (TRM-1, HGS-ETR1) is a fully human immunoglobulin G1 lambda (IgG1 $\lambda$ ) monoclonal antibody (mAb) agonist of TRAIL-R which has shown a tolerable toxicity profile during phase1 development (Tolcher et al., 2007). Researchers have observed promising preclinical activity with mapatumumab in patient with advanced solid cancers (Hotte et al., 2008). Currently, mapatumumab in combination with bortezomib in patients with refractory myeloma (Kapoor et al., 2012) and cisplatin and radiotherapyin patients with cervical cancer is in phase II clinical trials (Vici et al., 2014).

Lexatumumab (HGS-ETR2) is another fully human agonistic mAb that targets TRAIL-R2 and activates death receptor mediated pathway and has been evaluated in phase I/II settings (Sikic BI et al., 2007; Wakelee et al., 2010).

\section{Targeting $c-F L I P$}

C-FLIP is an important target for the development of siRNA that, in particular, inhibit the expression of c-FLIP in various human tumor cell lines and sensitize cancer cells to TRAIL, FASL, and chemotherapeutic agents (Day and Safa, 2009). However, there are many limitations for siRNA in vivo and the extensive utilization of targeting FLIP by siRNAs in clinical settings relies on the safe delivery of siRNA (Whitehead et al., 2009). Besides siRNA mediated down-regulation of c-FLIP, there are some small molecules that cause degradation of c-FLIP as well as down-regulating mRNA and protein levels of c-FLIPL and c-FLIPS splice variants (Safa and Pollok, 2011). It should be noted that due to the structural similarity of c-FLIP to caspase-8, small molecules which have the ability to inhibit c-FLIP's recruitment to the DISC could also block the recruitment of caspase-8, and, 
consequently, inhibit apoptosis. This resemblance makes the c-FLIP protein a very complex target for drugs to block c-FLIP function; thus, in order to inhibit c-FLIP expression, small molecules should be developed which inhibit c-FLIP without blocking caspase-8 and -10 (Safa and Pollok, 2011).

Several agents have been established that downregulate levels of c-FLIP through affecting c-FLIP transcription, degrading c-FLIP through the ubiquitin proteasome system, or decreasing c-FLIP translation (Safa et al., 2008; Safa and Pollok, 2011). Some of these agents include DNA damaging agents and chemotherapeutic drugs (such as cisplatin and Oxaliplatin), topoisomerase I inhibitors (camptothecin, 9-nitrocamptothecin (9NC), irinotecan) (Kinoshita et al., 2000; Chatterjee et al., 2001; Song et al., 2003; Galligan et al., 2005; Longley et al., 2006; Abedini et al., 2008), or Histone deacetylase (HDAC) inhibitors (such as suberoylanilidehydroxamic acid (SAHA, vorinostat), Depsipeptide, Trichostatin A, Valproic acid, MS-275 (entinostat)) (Pathil et al., 2006; Park et al., 2009; Rao-Bindal et al., 2013; Riley et al., 2013; Feng et al., 2014). One of the most promising HDAC inhibitors is SAHA, which causes degradation of c-FLIP variants via an ubiquitin/proteasome-dependent Itch/AIP4-independent mechanism (Yerbes and LopezRivas, 2012). Depsipeptide is another member of HDACi that leads to caspase-dependent apoptosis in chronic lymphocytic leukemia and osteosarcoma cells through selectively involving TNF-R (extrinsic pathway) and down-regulation of c-FLIP without evidence of Fas (CD95) up-regulation (Aron et al., 2003; Watanabe et al., 2005). Additionally, MS-275 has been reported to block c-FLIP expression in CLL, osteosarcoma and melanoma cells (Lucas et al., 2004; Rao-Bindal et al., 2013; Venza et al., 2014). Recently, a small molecule inhibitor of c-FLIP, 4-(4-Chloro-2-methylphenoxy)-N-hydroxybutanamide $(\mathrm{CMH})$, has been recognized as using a high-throughput chemical library screen (Schimmer et al., 2006). 4-(4-Chloro-2-methylphenoxy)-N-hydroxybutanamide (CMH) (5809354) down-regulates c-FLIP mRNA and protein levels, and causes degradation of PARP and reduces cell survival, as well as inducing apoptosis in cancer cells (Mawji et al., 2007b; Bijangi-Vishehsaraei et al., 2010). Moreover, an antipsychotic agent, Thioridazine, is known to have an anticancer activity due to the ability of thioridazine to sensitize TRAIL-mediated apoptosis and down-regulate c-FLIP(L) and Mcl-1 expression at the post-translational level (Min et al., 2014). Kerr et al. reported the Ku70/FLIP interaction affects FLIP protein stability by preventing its polyubiquitination. In addition, they showed that SAHA disrupts the FLIP/ $\mathrm{Ku} 70$ complex via increasing the acetylation of $\mathrm{Ku} 70$, which consequently triggers FLIP polyubiquitination and degradation by the proteasome (Kerr et al., 2012). C-FLIP has been demonstrated to be down-regulated by several compounds such as actinomycin D (Hernandez et al., 2001), cycloheximide (Kaminskyy et al., 2013), and anisomycin (Mawji et al., 2007a); the first is an RNA synthesis inhibitor, and the second and third are protein synthesis inhibitors. Moreover, protease inhibitors such as Bortezomib (PS-34) have been extensively studied and shown to have the ability to reduce c-FLIP in diverse cell lines (Koschny et al., 2007; Perez et al., 2010).

\section{Targeting IAPs}

Aberrantly high expression of IAP proteins has been reported to increase resistance to apoptotic stimuli in many cancer types (Wright and Duckett, 2005); based on the idea that IAPs contribute to blockage of apoptosis, this can provide new opportunities for cancer treatment through the development of drugs that can inhibit IAPs (Dubrez et al., 2013) . Presently, there are two approaches for inhibiting IAPs that include $(i)$ inhibiting IAPs by mimicking Smac, and (ii) anti-sense mediated interference of XIAP and survivin mRNA and protein expression.

Smac mimetic compounds (SMCS): Recently, several peptidic and non-peptidic small molecule pharmacologic inhibitors of IAP proteins that mimic the binding domain of Smac (SMAC mimetics) to IAP proteins have been developed (Fulda, 2014). Cyclopeptidic SMAC mimetics bind to the BIR2 or BIR3 domain of CIAP-1/2 and XIAP and restore the activity of caspases which have been blocked by IAPs (Sun et al., 2010). Alternatively, a nonpeptidic IAP inhibitor(SM-164) was described to increase TRAIL activity at the same time as targeting cIAP1and XIAP (Lu et al., 2011).

Numerous studies report the therapeutic effect of SMAC mimetics when used in combination with conventional chemotherapeutic drugs, radiation therapy or death receptor agonist. For example, Dai et al. (2009) have shown that the SMAC mimetic SH122 sensitizes human prostate cancer cells to TRAIL-induced apoptosis by inhibiting both IAPs and NF- $x \mathrm{~B}$. Moreover, they reported that another small-molecule inhibitor of IAPs, SH130, can increase ionizing-radiation-induced apoptosis in prostate cancer models (Dai et al., 2008). Varfolomeev E. et al. demonstrated that a SMAC mimetic which binds to cIAPs results in c-IAP auto-ubiquitination activity and proteasomal degradation (Varfolomeev et al., 2007).

Several SMAC mimetic compounds that have shown activity in cancer cell lines, include AZD5582, which sensitizes CLL cells to killing by TRAIL (Zhuang et al.), and JP1201 in NSCLC (Greer et al., 2011),HT-29 colorectal cancer(Huerta et al., 2010) cell lines, and multiple animal models of pancreatic cancer (Dineen et al., 2010). Interestingly, cIAPs target NF- $\varkappa$ B-inducing kinase (NIK), therefore acting as negative regulators of $\mathrm{NF}-x \mathrm{~B}$ activation, and inducing loss of cIAPs by SMAC mimetics leads to NIK stabilization and consequent NF- $x$ B activation (Baud and Karin, 2009). YM155 (sepantronium bromide) and EM1421 which are inhibitors of Birc5 transcription can antagonize survivin expression and induce apoptosis in human cancer cell lines (Nakahara et al., 2007). YM155, a selective small-molecule survivin suppressant, is currently in phase 2 trials in non-small cell lung carcinoma, solid tumors, prostate cancer and melanoma (Giaccone et al., 2009; Tolcher et al., 2012; Kudchadkar et al., 2014).

Antisense oligonucleotides and small siRNA molecules: Besides targeting IAPs through small molecule inhibitors and peptidomimetics, antisense oligonucleotides and short interfering RNA (siRNA) molecules have also 
been exploited to target survivin and XIAP in cancers (Dai et al., 2005; Karami et al., 2013). Several antisense have been described as down-regulating XIAP and surviving expression, such as AEG35156 (down-regulates XIAP expression) (Carter et al., 2011) and LY2181308 (binds to survivin mRNA and inhibits its expression) (Tanioka et al., 2011). Nevertheless, partial positive responses have been seen in clinical trials of existing IAPs using targeting strategies .YM155 monobromide is a small molecule survivin gene suppressant through binding to the Sp1 rich region of the promoter of survivin, and blocks the transcription of survivin in different cancer cell lines (Nakahara et al., 2007; Cheng et al., 2012). Croci DO et al. have shown that after siRNA transfection against survivin and down-regulation of survivin, translocation of the AIF from the cytoplasm to the nucleus occurs, which is a molecular indicator of the caspase-independent apoptosis of cells (Croci et al., 2008). Combined use of cisplatin, fluorouracil, paclitaxel, etoposide, and XIAP siRNA have been shown to result in better chemotherapeutic activity and to efficiently decrease XIAP expression and make it sensitive to cancer treatments (Zhang et al., 2007; Wei et al., 2008).

\section{Targeting caspases}

A number of drugs have been developed to synthetically activate caspases. For instance, Apoptin is a caspaseinducing agent which exerts a tumor-preferential apoptotic activity and selectively induces apoptosis in cancer but not normal cells (Rohn and Noteborn, 2004). Another class of drugs which are activators of caspases is the small molecule caspase activators. Small molecule caspase activators are characterized by presence of the arginineglycine-aspartate motif. These agents have the potential to decrease the activation threshold of caspase and to induce auto-activation of procaspase-3, and, finally, can sensitize cancer cells to chemotherapeutic agents (Philchenkov et al., 2004). Thus, targeting caspase- 8 expression may lead to a significant therapeutic effect, particularly in tumors suffering from a gene dosage effect or hypermethylation of caspase- 8 promoters. In this context, in tumors suffering from hypermethylation of caspase- 8 promoters, researchers are using 5-aza-2'deoxycytidine (decitabine), a cytosine nucleoside analog which inhibits DNA methyltransferase covalent binding and promotes demethylation. Additionally, there is evidence that shows 5-aza-2' deoxycytidine (decitabine) boosts caspase- 8 promoter availability, and provides a situation for binding of SP1 and ETS-like transcription factors (Liedtke et al., 2005; Fulda and Debatin, 2006).

Besides caspase-based drug therapy, caspase-based gene therapy has been tried. It has been shown that caspase-3 gene therapy, in addition to etoposide treatment, can induce widespread apoptosis and leads to reduction of tumor volume in an AH130 liver tumor model (Yamabe et al., 1999).

\section{Conclusion}

In conclusion, apoptosis is a cellular procedure that is closely regulated by diverse groups of regulatory molecules and is characterized by specific morphological and biochemical features in which activation of caspase plays a crucial role. One of the fundamental features of human cancers is evasion of apoptosis, which contributes to both tumor progression and resistance to cancer treatments. An enhanced understanding of the apoptotic signaling mechanisms, the key proteins involved in apoptosis, and the mechanisms by which cancer cells evade apoptotic death has led to effective therapeutic strategies to inhibit cancer cell proliferation, which will significantly benefit cancer patients. Some drugs that selectively target different components of apoptosis are in clinical trials, and the combination of these novel agents with traditional chemotherapy seems to be well tolerated.

\section{References}

Abedini MR, Muller EJ, Brun J, et al (2008). Cisplatin induces p53-dependent FLICE-like inhibitory protein ubiquitination in ovarian cancer cells. Cancer Res, 68, 4511-7.

Acehan D, Jiang X, Morgan DG, et al (2002). Three-dimensional structure of the apoptosome: implications for assembly, procaspase-9 binding, and activation. Mol Cell, 9, 423-32.

Albershardt TC, Salerni BL, Soderquist RS, et al (2011). Multiple BH3 mimetics antagonize antiapoptotic MCL1 protein by inducing the endoplasmic reticulum stress response and up-regulating BH3-only protein NOXA. J Biol Chem, 286, 24882-95.

Allegra D, Bilan V, Garding A, et al (2014). Defective DROSHA processing contributes to downregulation of MiR-15/-16 in chronic lymphocytic leukemia. Leukemia, 28, 2427.

Antonia SJ, Mirza N, Fricke I, et al (2006). Combination of p53 cancer vaccine with chemotherapy in patients with extensive stage small cell lung cancer. Clin Cancer Res, 12, 878-87.

Arbel N, Ben-Hail D, Shoshan-Barmatz V (2012). Mediation of the antiapoptotic activity of Bcl-xL protein upon interaction with VDAC1 protein. J Biol Chem, 287, 23152-61.

Aron JL, Parthun MR, Marcucci G, et al (2003). Depsipeptide (FR901228) induces histone acetylation and inhibition of histone deacetylase in chronic lymphocytic leukemia cells concurrent with activation of caspase 8-mediated apoptosis and down-regulation of c-FLIP protein. Blood, 102, 652-8.

Ashkenazi A, Pai RC, Fong S, et al (1999). Safety and antitumor activity of recombinant soluble Apo2 ligand. J Clin Invest, 104, 155-62.

Atencio IA, Grace M, Bordens R, et al (2006). Biological activities of a recombinant adenovirus p53 ( $\mathrm{SCH} 58500$ ) administered by hepatic arterial infusion in a Phase 1 colorectal cancer trial. Cancer Gene Ther, 13, 169-81.

Azmi AS, Mohammad RM (2009). Non-peptidic small molecule inhibitors against Bcl-2 for cancer therapy. J Cell Physiol, 218, 13-21.

Baron AT, O'Bryant CL, Choi Y, et al (2011). Phase Ib study of drozitumab combined with cetuximab (CET) plus irinotecan (IRI) or with FOLFIRI+/-bevacizumab (BV) in previously treated patients (Pts) with metastatic colorectal cancer (mCRC). J Clin Oncol, 29, [Epub ahead of print].

Bartholomeusz C, Itamochi H, Yuan LX, et al (2005). Bcl-2 antisense oligonucleotide overcomes resistance to E1A gene therapy in a low HER2-expressing ovarian cancer xenograft model. Cancer Res, 65, 8406-13.

Baud V, Karin M (2009). Is NF-kappaB a good target for cancer therapy? Hopes and pitfalls. Nat Rev Drug Discov, 8, 33-40.

Bijangi-Vishehsaraei K, Saadatzadeh MR, Huang S, et al (2010). 4-(4-Chloro-2-methylphenoxy)-N-hydroxybutanamide 
(CMH) targets mRNA of the c-FLIP variants and induces apoptosis in MCF-7 human breast cancer cells. Mol Cell Biochem, 342, 133-42.

Boatright KM, Renatus M, Scott FL, et al (2003). A unified model for apical caspase activation. Mol Cell, 11, 529-41.

Boeckler FM, Joerger AC, Jaggi G, et al (2008). Targeted rescue of a destabilized mutant of $\mathrm{p} 53$ by an in silico screened drug. Proc Natl Acad Sci U S A, 105, 10360-5.

Bose P, Grant S (2013). Mcl-1 as a Therapeutic Target in Acute Myelogenous Leukemia (AML). Leuk Res Rep, 2, 12-4.

Bykov VJ, Issaeva N, Zache N, et al (2005a). Reactivation of mutant p53 and induction of apoptosis in human tumor cells by maleimide analogs. J Biol Chem, 280, 30384-91.

Bykov VJ, Wiman KG (2014). Mutant p53 reactivation by small molecules makes its way to the clinic. FEBS Lett, $\mathbf{5 8 8}, 2622-7$.

Bykov VJ, Zache N, Stridh H, et al (2005b). PRIMA-1(MET) synergizes with cisplatin to induce tumor cell apoptosis. Oncogene, 24, 3484-91.

Calin GA, Cimmino A, Fabbri M, et al (2008). MiR-15a and miR-16-1 cluster functions in human leukemia. Proc Natl Acad Sci U S A, 105, 5166-71.

Carter BZ, Mak DH, Morris SJ, et al (2011). XIAP antisense oligonucleotide (AEG35156) achieves target knockdown and induces apoptosis preferentially in CD34+38- cells in a phase $1 / 2$ study of patients with relapsed/refractory AML. Apoptosis, 16, 67-74.

Chang DW, Xing Z, Pan Y, et al (2002). c-FLIP(L) is a dual function regulator for caspase-8 activation and CD95mediated apoptosis. Embo J, 21, 3704-14.

Chatterjee D, Schmitz I, Krueger A, et al (2001). Induction of apoptosis in 9-nitrocamptothecin-treated DU145 human prostate carcinoma cells correlates with de novo synthesis of CD95 and CD95 ligand and down-regulation of c-FLIP(short). Cancer Res, 61, 7148-54.

Chauhan D, Velankar M, Brahmandam M, et al (2007). A novel $\mathrm{Bcl}-2 / \mathrm{Bcl}-\mathrm{X}(\mathrm{L}) / \mathrm{Bcl}-\mathrm{w}$ inhibitor ABT-737 as therapy in multiple myeloma. Oncogene, 26, 2374-80.

Chen Y, Gao DY, Huang L (2014). In vivo delivery of miRNAs for cancer therapy: Challenges and strategies. Adv Drug Deliv Rev, 81, 128-41

Cheng Q, Ling X, Haller A, et al (2012). Suppression of survivin promoter activity by YM155 involves disruption of Sp1DNA interaction in the survivin core promoter. Int J Biochem Mol Biol, 3, 179-97.

Chi KN, Gleave ME, Klasa R, et al (2001). A phase I dosefinding study of combined treatment with an antisense Bcl-2 oligonucleotide (Genasense) and mitoxantrone in patients with metastatic hormone-refractory prostate cancer. Clin Cancer Res, 7, 3920-7.

Chi SW (2014). Structural insights into the transcriptionindependent apoptotic pathway of p53. BMB Rep, 47, 167-72.

Chipuk JE, Bouchier-Hayes L, Green DR (2006). Mitochondrial outer membrane permeabilization during apoptosis: the innocent bystander scenario. Cell Death Differ, 13, 1396402.

Chipuk JE, Kuwana T, Bouchier-Hayes L, et al (2004). Direct activation of Bax by $\mathrm{p} 53$ mediates mitochondrial membrane permeabilization and apoptosis. Science, 303, 1010-4.

Chu ZL, McKinsey TA, Liu L, et al (1997). Suppression of tumor necrosis factor-induced cell death by inhibitor of apoptosis c-IAP2 is under NF-kappaB control. Proc Natl Acad Sci U $S A, 94,10057-62$.

Cimmino A, Calin GA, Fabbri M, et al (2005). miR-15 and miR16 induce apoptosis by targeting BCL2. Proc Natl Acad Sci U S A, 102, 13944-9.
Cohen EE, Rudin CM (2001). ONYX-015. Onyx Pharmaceuticals. Curr Opin Investig Drugs, 2 , 1770-5.

Croce CM (2009). Causes and consequences of microRNA dysregulation in cancer. Nat Rev Genet, 10, 704-14.

Croci DO, Cogno IS, Vittar NB, et al (2008). Silencing survivin gene expression promotes apoptosis of human breast cancer cells through a caspase-independent pathway. J Cell Biochem, 105, 381-90.

Czabotar PE, Lessene G, Strasser A, et al (2014). Control of apoptosis by the BCL-2 protein family: implications for physiology and therapy. Nat Rev Mol Cell Biol, 15, 49-63.

Dai DJ, Lu CD, Lai RY, et al (2005). Survivin antisense compound inhibits proliferation and promotes apoptosis in liver cancer cells. World J Gastroenterol, 11, 193-9.

Dai Y, Liu M, Tang W, et al (2008). Molecularly targeted radiosensitization of human prostate cancer by modulating inhibitor of apoptosis. Clin Cancer Res, 14, 7701-10.

Dai Y, Liu M, Tang W, et al (2009). A Smac-mimetic sensitizes prostate cancer cells to TRAIL-induced apoptosis via modulating both IAPs and NF-kappaB. BMC Cancer, 9, 392 .

Day TW, Safa AR (2009). RNA interference in cancer: targeting the anti-apoptotic protein c-FLIP for drug discovery. Mini Rev Med Chem, 9, 741-8.

de Almagro MC, Vucic D (2012). The inhibitor of apoptosis (IAP) proteins are critical regulators of signaling pathways and targets for anti-cancer therapy. Exp Oncol, 34, 200-11.

De Cesare M, Perego P, Righetti SC, et al (2005). Enhanced antitumour efficacy of gimatecan in combination with Bcl-2 antisense oligonucleotide in human melanoma xenografts. Eur J Cancer, 41, 1213-22.

Demma M, Maxwell E, Ramos R, et al (2010). SCH529074, a small molecule activator of mutant p53, which binds $\mathrm{p} 53$ DNA binding domain (DBD), restores growth-suppressive function to mutant p53 and interrupts HDM2-mediated ubiquitination of wild type p53. J Biol Chem, 285, 10198212.

Devarajan E, Sahin AA, Chen JS, et al (2002). Down-regulation of caspase 3 in breast cancer: a possible mechanism for chemoresistance. Oncogene, 21, 8843-51.

Dineen SP, Roland CL, Greer R, et al (2010). Smac mimetic increases chemotherapy response and improves survival in mice with pancreatic cancer. Cancer Res, 70, 2852-61.

Duan H, Heckman CA, Boxer LM (2005). Histone deacetylase inhibitors down-regulate bcl-2 expression and induce apoptosis in t $(14 ; 18)$ lymphomas. Mol Cell Biol, 25, 160819.

Dubrez L, Berthelet J, Glorian V (2013). IAP proteins as targets for drug development in oncology. Onco Targets Ther, $\mathbf{9}$, 1285-304

Duggan BJ, Maxwell P, Kelly JD, et al (2001). The effect of antisense $\mathrm{Bcl}-2$ oligonucleotides on $\mathrm{Bcl}-2$ protein expression and apoptosis in human bladder transitional cell carcinoma. J Urol, 166, 1098-105.

Eckelman BP, Salvesen GS, Scott FL (2006). Human inhibitor of apoptosis proteins: why XIAP is the black sheep of the family. EMBO Rep, 7, 988-94.

Elmore S (2007). Apoptosis: a review of programmed cell death. Toxicol Pathol, 35, 495-516.

Emi M, Kim R, Tanabe K, et al (2005). Targeted therapy against Bcl-2-related proteins in breast cancer cells. Breast Cancer Res, 7, 940-52.

Feng W, Zhang B, Cai D, et al (2014). Therapeutic potential of histone deacetylase inhibitors in pancreatic cancer. Cancer Lett, 347, 183-90.

Fong PY, Xue WC, Ngan HY, et al (2006). Caspase activity is downregulated in choriocarcinoma: a cDNA array differential expression study. J Clin Pathol, 59, 179-83. 
Fulda S (2009). Tumor resistance to apoptosis. Int J Cancer, 124, $511-5$.

Fulda $\mathrm{S}$ (2010). Evasion of apoptosis as a cellular stress response in cancer. Int J Cell Biol, 2010, 370835.

Fulda S (2014). Molecular pathways: targeting inhibitor of apoptosis proteins in cancer-from molecular mechanism to therapeutic application. Clin Cancer Res, 20, 289-95.

Fulda S, Debatin KM (2006). 5-Aza-2'-deoxycytidine and IFNgamma cooperate to sensitize for TRAIL-induced apoptosis by upregulating caspase-8. Oncogene, 25, 5125-33.

Galligan L, Longley DB, McEwan M, et al (2005). Chemotherapy and TRAIL-mediated colon cancer cell death: the roles of p53, TRAIL receptors, and c-FLIP. Mol Cancer Ther, 4 2026-36.

Galluzzi L, Morselli E, Kepp O, et al (2010). Mitochondrial gateways to cancer. Mol Aspects Med, 31, 1-20.

Garofalo M, Condorelli GL, Croce CM, et al (2010). MicroRNAs as regulators of death receptors signaling. Cell Death Differ, 17, 200-8.

Garofalo M, Croce CM (2011). microRNAs: Master regulators as potential therapeutics in cancer. Annu Rev Pharmacol Toxicol, 51, 25-43.

Garofalo M, Quintavalle C, Di Leva G, et al (2008). MicroRNA signatures of TRAIL resistance in human non-small cell lung cancer. Oncogene, 27, 3845-55.

Giaccone G, Zatloukal P, Roubec J, et al (2009). Multicenter phase II trial of YM155, a small-molecule suppressor of survivin, in patients with advanced, refractory, non-smallcell lung cancer. $J$ Clin Oncol, 27, 4481-6.

Green DR, Evan GI (2002). A matter of life and death. Cancer Cell, 1, 19-30.

Greer RM, Peyton M, Larsen JE, et al (2011). SMAC mimetic (JP1201) sensitizes non-small cell lung cancers to multiple chemotherapy agents in an IAP-dependent but TNF-alphaindependent manner. Cancer Res, 71, 7640-8.

Grillier-Vuissoz, Isabelle ea (2012). PPAR $\gamma$-independent Activity of Thiazolidinediones: A Promising Mechanism of Action for New Anticancer Drugs. J Carcinogene Mutagene

Guicciardi ME, Gores GJ (2009). Life and death by death receptors. FASEB J, 23, 1625-37.

Gustafsson AB, Gottlieb RA (2008). Heart mitochondria: gates of life and death. Cardiovasc Res, 77, 334-43.

Hamanaka RB, Bobrovnikova-Marjon E, Ji X, et al (2009). PERK-dependent regulation of IAP translation during ER stress. Oncogene, 28, 910-20.

Hassan M, Watari H, AbuAlmaaty A, et al (2014). Apoptosis and molecular targeting therapy in cancer. Biomed Res Int, 2014, 150845 .

Hassen S, Ali N, Chowdhury P (2012). Molecular signaling mechanisms of apoptosis in hereditary non-polyposis colorectal cancer. World J Gastrointest Pathophysiol, 3, 71-9.

Hawkins CJ, Silke J, Verhagen AM, et al (2001). Analysis of candidate antagonists of IAP-mediated caspase inhibition using yeast reconstituted with the mammalian Apaf-1activated apoptosis mechanism. Apoptosis, 6, 331-8.

Hernandez A, Wang QD, Schwartz SA, et al (2001). Sensitization of human colon cancer cells to TRAIL-mediated apoptosis. J Gastrointest Surg, 5, 56-65.

Herrero Martin D, Boro A, Schafer BW (2013). Cell-based smallmolecule compound screen identifies fenretinide as potential therapeutic for translocation-positive rhabdomyosarcoma. PLoS One, 8, 55072.

Hinds MG, Norton RS, Vaux DL, et al (1999). Solution structure of a baculoviral inhibitor of apoptosis (IAP) repeat. Nat Struct Biol, 6, 648-51.

Hong B, van den Heuvel AP, Prabhu VV, et al (2014). Targeting tumor suppressor p53 for cancer therapy: strategies, challenges and opportunities. Curr Drug Targets, 15, 80-9.

Hotte SJ, Hirte HW, Chen EX, et al (2008). A phase 1 study of mapatumumab (fully human monoclonal antibody to TRAIL-R1) in patients with advanced solid malignancies. Clin Cancer Res, 14, 3450-5.

$\mathrm{Hu} \mathrm{Q}, \mathrm{Wu} \mathrm{D}$, Chen W, et al (2013). Proteolytic processing of the caspase- 9 zymogen is required for apoptosome-mediated activation of caspase-9. J Biol Chem, 288, 15142-7.

$\mathrm{Hu}$ Y, Bebb G, Tan S, et al (2004). Antitumor efficacy of oblimersen Bcl-2 antisense oligonucleotide alone and in combination with vinorelbine in xenograft models of human non-small cell lung cancer. Clin Cancer Res, 10, 7662-70.

Huerta S, Gao X, Livingston EH, et al (2010). In vitro and in vivo radiosensitization of colorectal cancer HT-29 cells by the smac mimetic JP-1201. Surgery, 148, 346-53.

Iancu-Rubin C, Mosoyan G, Glenn K, et al (2014). Activation of p53 by the MDM2 inhibitor RG7112 impairs thrombopoiesis. Exp Hematol, 42, 137-45.

Ichikawa K, Liu W, Zhao L, et al (2001). Tumoricidal activity of a novel anti-human DR5 monoclonal antibody without hepatocyte cytotoxicity. Nat Med, 7, 954-60.

Jin Z, El-Deiry WS (2005). Overview of cell death signaling pathways. Cancer Biol Ther, 4, 139-63.

Kaminskyy VO, Surova OV, Piskunova T, et al (2013). Upregulation of c-FLIP-short in response to TRAIL promotes survival of NSCLC cells, which could be suppressed by inhibition of $\mathrm{Ca} 2+/$ calmodulin signaling. Cell Death Dis, 4, 522.

Kang MH, Reynolds CP (2009). Bcl-2 inhibitors: targeting mitochondrial apoptotic pathways in cancer therapy. Clin Cancer Res, 15, 1126-32.

Kapoor P, Ramakrishnan V, Rajkumar SV (2012). Bortezomib combination therapy in multiple myeloma. Semin Hematol, 49, 228-42.

Karami H, Baradaran B, Esfahani A, et al (2013). siRNAmediated silencing of survivin inhibits proliferation and enhances etoposide chemosensitivity in acute myeloid leukemia cells. Asian Pac J Cancer Prev, 14, 7719-24.

Karami H, Baradaran B, Esfehani A, et al (2014). Downregulation of Mcl-1 by small interference RNA induces apoptosis and sensitizes HL-60 leukemia cells to etoposide. Asian Pac J Cancer Prev, 15, 629-35.

Kerr E, Holohan C, McLaughlin KM, et al (2012). Identification of an acetylation-dependant Ku70/FLIP complex that regulates FLIP expression and HDAC inhibitor-induced apoptosis. Cell Death Differ, 19, 1317-27.

Kerr JF, Wyllie AH, Currie AR (1972). Apoptosis: a basic biological phenomenon with wide-ranging implications in tissue kinetics. Br J Cancer, 26, 239-57.

Khan KH, Blanco-Codesido M, Molife LR (2014). Cancer therapeutics: Targeting the apoptotic pathway. Crit Rev Oncol Hematol, 90, 200-19.

Khosravi-Far R, Esposti MD (2004). Death receptor signals to mitochondria. Cancer Biol Ther, 3, 1051-7.

Kinoshita H, Yoshikawa H, Shiiki K, et al (2000). Cisplatin (CDDP) sensitizes human osteosarcoma cell to Fas/CD95mediated apoptosis by down-regulating FLIP-Lexpression. Int J Cancer, 88, 986-91.

Kitada S, Zapata JM, Andreeff M, et al (2000). Protein kinase inhibitors flavopiridol and 7-hydroxy-staurosporine downregulate antiapoptosis proteins in B-cell chronic lymphocytic leukemia. Blood, 96, 393-7.

Koschny R, Holland H, Sykora J, et al (2007). Bortezomib sensitizes primary human astrocytoma cells of WHO grades I to IV for tumor necrosis factor-related apoptosis-inducing ligand-induced apoptosis. Clin Cancer Res, 13, 3403-12.

Kroemer G, Dallaporta B, Resche-Rigon M (1998). The 
mitochondrial death/life regulator in apoptosis and necrosis. Annu Rev Physiol, 60, 619-42.

Kuball J, Schuler M, Antunes Ferreira E, et al (2002). Generating p53-specific cytotoxic $\mathrm{T}$ lymphocytes by recombinant adenoviral vector-based vaccination in mice, but not man. Gene Ther, 9, 833-43.

Kudchadkar R, Ernst S, Chmielowski B, et al (2014). A phase 2, multicenter, open-label study of sepantronium bromide (YM155) plus docetaxel in patients with stage III (unresectable) or stage IV melanoma. Cancer Med [Epub ahead of print].

Lau R, Pratt MA (2012). The opposing roles of cellular inhibitor of apoptosis proteins in cancer. ISRN Oncol, 2012, 928120.

Leffers N, Lambeck AJ, Gooden MJ, et al (2009). Immunization with a P53 synthetic long peptide vaccine induces P53specific immune responses in ovarian cancer patients, a phase II trial. Int J Cancer, 125, 2104-13.

Lehmann S, Bykov VJ, Ali D, et al (2012). Targeting p53 in vivo: a first-in-human study with p53-targeting compound APR246 in refractory hematologic malignancies and prostate cancer. J Clin Oncol, 30, 3633-9.

Leonetti C, Biroccio A, D’Angelo C, et al (2007). Therapeutic integration of c-myc and bcl-2 antisense molecules with docetaxel in a preclinical model of hormone-refractory prostate cancer. Prostate, 67, 1475-85.

Li J, Yuan J (2008). Caspases in apoptosis and beyond. Oncogene, 27, 6194-206.

Li LY, Luo X, Wang X (2001). Endonuclease G is an apoptotic DNase when released from mitochondria. Nature, 412, 95-9.

Liedtke C, Zschemisch NH, Cohrs A, et al (2005). Silencing of caspase- 8 in murine hepatocellular carcinomas is mediated via methylation of an essential promoter element. Gastroenterology, 129, 1602-15.

Lima RT, Busacca S, Almeida GM, et al (2011). MicroRNA regulation of core apoptosis pathways in cancer. Eur $J$ Cancer, 47, 163-74.

Liu G, Kelly WK, Wilding G, et al (2009). An open-label, multicenter, phase I/II study of single-agent AT-101 in men with castrate-resistant prostate cancer. Clin Cancer Res, $\mathbf{1 5}, 3172-6$.

Liu Z, Li H, Derouet M, et al (2005). ras Oncogene triggers up-regulation of cIAP2 and XIAP in intestinal epithelial cells: epidermal growth factor receptor-dependent and -independent mechanisms of ras-induced transformation. $J$ Biol Chem, 280, 37383-92.

Liu Z, Li H, Wu X, et al (2006). Detachment-induced upregulation of XIAP and cIAP2 delays anoikis of intestinal epithelial cells. Oncogene, 25, 7680-90.

Longley DB, Wilson TR, McEwan M, et al (2006). c-FLIP inhibits chemotherapy-induced colorectal cancer cell death. Oncogene, 25, 838-48.

Lu J, McEachern D, Sun H, et al (2011). Therapeutic potential and molecular mechanism of a novel, potent, nonpeptide, Smac mimetic SM-164 in combination with TRAIL for cancer treatment. Mol Cancer Ther, 10, 902-14.

Lucas DM, Davis ME, Parthun MR, et al (2004). The histone deacetylase inhibitor MS-275 induces caspase-dependent apoptosis in B-cell chronic lymphocytic leukemia cells. Leukemia, 18, 1207-14.

Martinez-Caballero S, Dejean LM, Kinnally MS, et al (2009). Assembly of the mitochondrial apoptosis-induced channel, MAC. J Biol Chem, 284, 12235-45.

Matthew S. Davids M (2013). The single-agent Bcl-2 inhibitor ABT-199 (GDC-0199) in patients with relapsed/refractory (R/R) non-hodgkin lymphoma (NHL): responses observed in all mantle cell lymphoma (MCL) patients. american society of hematology [Epub ahead of print].
Mawji IA, Simpson CD, Gronda M, et al (2007a). A chemical screen identifies anisomycin as an anoikis sensitizer that functions by decreasing FLIP protein synthesis. Cancer Res, 67, 8307-15.

Mawji IA, Simpson CD, Hurren R, et al (2007b). Critical role for Fas-associated death domain-like interleukin-1-converting enzyme-like inhibitory protein in anoikis resistance and distant tumor formation. J Natl Cancer Inst, 99, 811-22.

Menon AG, Kuppen PJ, van der Burg SH, et al (2003). Safety of intravenous administration of a canarypox virus encoding the human wild-type p53 gene in colorectal cancer patients. Cancer Gene Ther, 10, 509-17.

Micheau O (2003). Cellular FLICE-inhibitory protein: an attractive therapeutic target? Expert Opin Ther Targets, 7, 559-73.

Micheau O, Lens S, Gaide O, et al (2001). NF-kappaB signals induce the expression of c-FLIP. Mol Cell Biol, 21, 5299-305.

Min KJ, Seo BR, Bae YC, et al (2014). Antipsychotic agent thioridazine sensitizes renal carcinoma Caki cells to TRAILinduced apoptosis through reactive oxygen species-mediated inhibition of Akt signaling and downregulation of Mcl-1 and c-FLIP(L). Cell Death Dis, 5, 1063.

Mirza A, McGuirk M, Hockenberry TN, et al (2002). Human survivin is negatively regulated by wild-type p53 and participates in p53-dependent apoptotic pathway. Oncogene, 21, 2613-22.

Mukhopadhyay S, Panda PK, Sinha N, et al (2014). Autophagy and apoptosis: where do they meet? Apoptosis, 19, 555-66.

Nakahara T, Kita A, Yamanaka K, et al (2007). YM155, a novel small-molecule survivin suppressant, induces regression of established human hormone-refractory prostate tumor xenografts. Cancer Res, 67, 8014-21.

Nemunaitis J, Ganly I, Khuri F, et al (2000). Selective replication and oncolysis in p53 mutant tumors with ONYX-015, an E1B-55kD gene-deleted adenovirus, in patients with advanced head and neck cancer: a phase II trial. Cancer Res, 60, 6359-66.

O'Brien S, Moore J, Boyd T, et al (2009). 5-year survival in patients with relapsed or refractory chronic lymphocytic leukemia in a randomized, phase III trial of fludarabine plus cyclophosphamide with or without oblimersen. J Clin Oncol, 5208-12.

Oliner JD, Pietenpol JA, Thiagalingam S, et al (1993). Oncoprotein MDM2 conceals the activation domain of tumour suppressor p53. Nature, 362, 857-60.

Oltersdorf T, Elmore SW, Shoemaker AR, et al (2005). An inhibitor of Bcl-2 family proteins induces regression of solid tumours. Nature, 435, 677-81.

Ouyang L, Shi Z, Zhao S, et al (2012). Programmed cell death pathways in cancer: a review of apoptosis, autophagy and programmed necrosis. Cell Prolif, 45, 487-98.

P: C (2001). p53 as a drug target in cancer therapy. Expert Opin Ther Patents, 923-35.

Park SJ, Kim MJ, Kim HB, et al (2009). Trichostatin a sensitizes human ovarian cancer cells to TRAIL-induced apoptosis by down-regulation of c-FLIPL via inhibition of EGFR pathway. Biochem Pharmacol, 77, 1328-36.

Pathil A, Armeanu S, Venturelli S, et al (2006). HDAC inhibitor treatment of hepatoma cells induces both TRAILindependent apoptosis and restoration of sensitivity to TRAIL. Hepatology, 43, 425-34.

Pei XY, Dai Y, Grant S (2004). The small-molecule Bcl-2 inhibitor HA14-1 interacts synergistically with flavopiridol to induce mitochondrial injury and apoptosis in human myeloma cells through a free radical-dependent and Jun NH2-terminal kinase-dependent mechanism. Mol Cancer Ther, 3, 1513-24. 
Perez LE, Parquet N, Meads M, et al (2010). Bortezomib restores stroma-mediated APO2L/TRAIL apoptosis resistance in multiple myeloma. Eur J Haematol, 84, 212-22.

Philchenkov A, Zavelevich M, Kroczak TJ, et al (2004). Caspases and cancer: mechanisms of inactivation and new treatment modalities. Exp Oncol, 26, 82-97.

Plati J, Bucur O, Khosravi-Far R (2011). Apoptotic cell signaling in cancer progression and therapy. Integr Biol (Camb), $\mathbf{3}$, 279-96.

Prezma T, Shteinfer A, Admoni L, et al (2013). VDAC1based peptides: novel pro-apoptotic agents and potential therapeutics for B-cell chronic lymphocytic leukemia. Cell Death Dis, 4, 809.

Qiu J, Gao Z, Shima H (2012). Growth of human prostate cancer cells is significantly suppressed in vitro with sodium butyrate through apoptosis. Oncol Rep, 27, 160-7.

Rao-Bindal K, Koshkina NV, Stewart J, et al (2013). The histone deacetylase inhibitor, MS-275 (entinostat), downregulates c-FLIP, sensitizes osteosarcoma cells to FasL, and induces the regression of osteosarcoma lung metastases. Curr Cancer Drug Targets, 13, 411-22.

Reesink-Peters N, Hougardy BM, van den Heuvel FA, et al (2005). Death receptors and ligands in cervical carcinogenesis: an immunohistochemical study. Gynecol Oncol, 96, 705-13.

Riley JS, Hutchinson R, McArt DG, et al (2013). Prognostic and therapeutic relevance of FLIP and procaspase- 8 overexpression in non-small cell lung cancer. Cell Death Dis, $\mathbf{4}, 951$.

Rohn JL, Noteborn MH (2004). The viral death effector Apoptin reveals tumor-specific processes. Apoptosis, 9, 315-22.

Rossi MN, Antonangeli F (2014). LncRNAs: New Players in Apoptosis Control. Intern J Cell Biology, 2014.

Roy MJ, Vom A, Czabotar PE, et al (2014). Cell death and the mitochondria: therapeutic targeting of the BCL-2 familydriven pathway. Br J Pharmacol, 171, 1973-87.

Rudin CM, Hann CL, Garon EB, et al (2012). Phase II study of single-agent navitoclax (ABT-263) and biomarker correlates in patients with relapsed small cell lung cancer. Clin Cancer Res, 18, 3163-9.

Safa AR, Day TW, Wu CH (2008). Cellular FLICE-like inhibitory protein (C-FLIP): a novel target for cancer therapy. Curr Cancer Drug Targets, 8, 37-46.

Safa AR, Pollok KE (2011). Targeting the Anti-Apoptotic Protein c-FLIP for Cancer Therapy. Cancers (Basel), 3, 1639-71.

Saleem M, Qadir MI, Perveen N, et al (2013). Inhibitors of apoptotic proteins: new targets for anticancer therapy. Chem Biol Drug Des, 82, 243-51.

Schimmer AD, Thomas MP, Hurren R, et al (2006). Identification of small molecules that sensitize resistant tumor cells to tumor necrosis factor-family death receptors. Cancer Res, 66, 2367-75.

Sevrioukova IF (2011). Apoptosis-inducing factor: structure, function, and redox regulation. Antioxid Redox Signal, 14, 2545-79.

Sharma S, de Vries EG, Infante JR, et al (2014). Safety, pharmacokinetics, and pharmacodynamics of the DR5 antibody LBY135 alone and in combination with capecitabine in patients with advanced solid tumors. Invest New Drugs, 32, 135-44.

Shiau CW, Yang CC, Kulp SK, et al (2005). Thiazolidenediones mediate apoptosis in prostate cancer cells in part through inhibition of Bcl-xL/Bcl-2 functions independently of PPARgamma. Cancer Res, 65, 1561-9.

Shin H, Lee YS, Lee YC (2012a). Sodium butyrate-induced DAPK-mediated apoptosis in human gastric cancer cells. Oncol Rep, 27, 1111-5.
Shin JS, Ha JH, Chi SW (2014). Targeting of p53 peptide analogues to anti-apoptotic Bcl-2 family proteins as revealed by NMR spectroscopy. Biochem Biophys Res Commun, 443, 882-7.

Shin JS, Ha JH, He F, et al (2012b). Structural insights into the dual-targeting mechanism of Nutlin-3. Biochem Biophys Res Commun, 420, 48-53.

Shirley S, Micheau O (2013). Targeting c-FLIP in cancer. Cancer Lett, 332, 141-50.

Shoshan-Barmatz V, De Pinto V, Zweckstetter M, et al (2010). VDAC, a multi-functional mitochondrial protein regulating cell life and death. Mol Aspects Med, 31, 227-85.

Shoshan-Barmatz V, Mizrachi D (2012). VDAC1: from structure to cancer therapy. Front Oncol, 2, 164.

Sikic BI et al $(2007$,$) . A phase Ib study toassess the safety$ of lexatumumab, a human monoclonal antibody thatactivates TRAIL-R2, in combination with gemcitabine, pemetrexed, doxorubicin or FOLFIRI.

Singh R, Saini N (2012). Downregulation of BCL2 by miRNAs augments drug-induced apoptosis-a combined computational and experimental approach. J Cell Sci, 125, 1568-78.

Song JH, Song DK, Herlyn M, et al (2003). Cisplatin downregulation of cellular Fas-associated death domain-like interleukin-1beta-converting enzyme-like inhibitory proteins to restore tumor necrosis factor-related apoptosis-inducing ligand-induced apoptosis in human melanoma cells. Clin Cancer Res, 9, 4255-66.

Sosin AM, Burger AM, Siddiqi A, et al (2012). HDM2 antagonist MI-219 (spiro-oxindole), but not Nutlin-3 (cis-imidazoline), regulates p53 through enhanced HDM2 autoubiquitination and degradation in human malignant B-cell lymphomas. $J$ Hematol Oncol, 5, 57.

Speetjens FM, Kuppen PJ, Welters MJ, et al (2009). Induction of p53-specific immunity by a p53 synthetic long peptide vaccine in patients treated for metastatic colorectal cancer. Clin Cancer Res, 15, 1086-95.

Spierings DC, de Vries EG, Vellenga E, et al (2004). Tissue distribution of the death ligand TRAIL and its receptors. $J$ Histochem Cytochem, 52, 821-31.

Subramaniam K, Hirpara JL, Tucker-Kellogg L, et al (2013). FLIP: a flop for execution signals. Cancer Lett, 332, 151-5.

Sun H, Kapuria V, Peterson LF, et al (2011). Bcr-Abl ubiquitination and Usp9x inhibition block kinase signaling and promote CML cell apoptosis. Blood, 117, 3151-62.

Sun H, Liu L, Lu J, et al (2010). Cyclopeptide Smac mimetics as antagonists of IAP proteins. Bioorg Med Chem Lett, 20, 3043-6.

Sun Y, Peng ZL (2009). Programmed cell death and cancer. Postgrad Med J, 85, 134-40.

Sung B, Park B, Yadav VR, et al (2010). Celastrol, a triterpene, enhances TRAIL-induced apoptosis through the downregulation of cell survival proteins and up-regulation of death receptors. J Biol Chem, 285, 11498-507.

Svane IM, Pedersen AE, Johansen JS, et al (2007). Vaccination with p53 peptide-pulsed dendritic cells is associated with disease stabilization in patients with p53 expressing advanced breast cancer; monitoring of serum YKL-40 and IL-6 as response biomarkers. Cancer Immunol Immunother, 56, 1485-99.

Svane IM, Pedersen AE, Johnsen HE, et al (2004). Vaccination with p53-peptide-pulsed dendritic cells, of patients with advanced breast cancer: report from a phase I study. Cancer Immunol Immunother, 53, 633-41.

Szegezdi E, Logue SE, Gorman AM, et al (2006). Mediators of endoplasmic reticulum stress-induced apoptosis. EMBO Rep, 7, 880-5.

Tabernero J, Dirix L, Schoffski P, et al (2011). A phase I first- 
in-human pharmacokinetic and pharmacodynamic study of serdemetan in patients with advanced solid tumors. Clin Cancer Res, 17, 6313-21.

Tagscherer KE, Fassl A, Campos B, et al (2008). Apoptosisbased treatment of glioblastomas with ABT-737, a novel small molecule inhibitor of Bcl-2 family proteins. Oncogene, 27, 6646-56.

Tajeddine N, Galluzzi L, Kepp O, et al (2008). Hierarchical involvement of Bak, VDAC1 and Bax in cisplatin-induced cell death. Oncogene, 27, 4221-32.

Tanioka M, Nokihara H, Yamamoto N, et al (2011). Phase I study of LY2181308, an antisense oligonucleotide against survivin, in patients with advanced solid tumors. Cancer Chemother Pharmacol, 68, 505-11.

Tchoghandjian A, Jennewein C, Eckhardt I, et al (2013). Identification of non-canonical NF-kappaB signaling as a critical mediator of Smac mimetic-stimulated migration and invasion of glioblastoma cells. Cell Death Dis, 4, 564.

Tiberio P, Cavadini E, Abolafio G, et al (2010). 4-oxo-N-(4hydroxyphenyl)retinamide: two independent ways to kill cancer cells. PLoS One, 5, 13362.

Tolcher AW, Mita M, Meropol NJ, et al (2007). Phase I pharmacokinetic and biologic correlative study of mapatumumab, a fully human monoclonal antibody with agonist activity to tumor necrosis factor-related apoptosisinducing ligand receptor-1. J Clin Oncol, 25, 1390-5.

Tolcher AW, Quinn DI, Ferrari A, et al (2012). A phase II study of YM155, a novel small-molecule suppressor of survivin, in castration-resistant taxane-pretreated prostate cancer. Ann Oncol, 23, 968-73.

Touzeau C, Dousset C, Le Gouill S, et al (2014). The Bcl-2 specific BH3 mimetic ABT-199: a promising targeted therapy for $\mathrm{t}(11 ; 14)$ multiple myeloma. Leukemia, 28, 210-2.

Travert M, Ame-Thomas P, Pangault C, et al (2008). CD40 ligand protects from TRAIL-induced apoptosis in follicular lymphomas through NF-kappaB activation and up-regulation of c-FLIP and Bcl-xL. J Immunol, 181, 1001-11.

Trudel S, Stewart AK, Li Z, et al (2007). The Bcl-2 family protein inhibitor, ABT-737, has substantial antimyeloma activity and shows synergistic effect with dexamethasone and melphalan. Clin Cancer Res, 13, 621-9.

Vaillant F, Merino D, Lee L, et al (2013). Targeting BCL-2 with the BH3 mimetic ABT-199 in estrogen receptor-positive breast cancer. Cancer Cell, 24, 120-9.

Van Poznak C, Seidman AD, Reidenberg MM, et al (2001). Oral gossypol in the treatment of patients with refractory metastatic breast cancer: a phase I/II clinical trial. Breast Cancer Res Treat, 66, 239-48.

Vande Walle L, Lamkanfi M, Vandenabeele P (2008). The mitochondrial serine protease HtrA2/Omi: an overview. Cell Death Differ, 15, 453-60.

Varfolomeev E, Blankenship JW, Wayson SM, et al (2007). IAP antagonists induce autoubiquitination of c-IAPs, NFkappaB activation, and TNFalpha-dependent apoptosis. Cell, 131, 669-81.

Venza I, Visalli M, Oteri R, et al (2014). Class I-specific histone deacetylase inhibitor MS-275 overrides TRAILresistance in melanoma cells by downregulating c-FLIP. Int Immunopharmacol, 21, 439-46.

Vermeij R, Leffers N, van der Burg SH, et al (2011). Immunological and clinical effects of vaccines targeting p53-overexpressing malignancies. J Biomed Biotechnol, 2011, 702146.

Vici P, Mariani L, Pizzuti L, et al (2014). Emerging biological treatments for uterine cervical carcinoma. J Cancer, 5, 86-97.

Wacheck V, Heere-Ress E, Halaschek-Wiener J, et al (2001). Bcl-2 antisense oligonucleotides chemosensitize human gastric cancer in a SCID mouse xenotransplantation model. J Mol Med (Berl), 79, 587-93.

Wakelee HA, Patnaik A, Sikic BI, et al (2010). Phase I and pharmacokinetic study of lexatumumab (HGS-ETR2) given every 2 weeks in patients with advanced solid tumors. Ann Oncol, 21, 376-81.

Wang S, Zhao Y, Bernard D, et al (2012). Targeting the MDM2-p53 protein-protein interaction for new cancer therapeutics. Springer Berlin Heidelberg??, 57-79.

Wang Y, Lee CG (2009). MicroRNA and cancer--focus on apoptosis. J Cell Mol Med, 13, 12-23.

Watanabe K, Okamoto K, Yonehara S (2005). Sensitization of osteosarcoma cells to death receptor-mediated apoptosis by HDAC inhibitors through downregulation of cellular FLIP. Cell Death Differ, 12, 10-8.

Wea RA (2012). Selective inhibition of BCL-2 is active against chronic lymphocytic leukemia (CLL): first clinical experience with the $\mathrm{BH} 3$-mimetic ABT-199. Haematologica, 97, 257-8.

Wei Y, Fan T, Yu M (2008). Inhibitor of apoptosis proteins and apoptosis. Acta Biochim Biophys Sin (Shanghai), 40, 278-88.

Weyhenmeyer B, Murphy AC, Prehn JH, et al (2012). Targeting the anti-apoptotic Bcl-2 family members for the treatment of cancer. Exp Oncol, 34, 192-9.

Whitehead KA, Langer R, Anderson DG (2009). Knocking down barriers: advances in siRNA delivery. Nat Rev Drug Discov, 8, 129-38.

Wright CW, Duckett CS (2005). Reawakening the cellular death program in neoplasia through the therapeutic blockade of IAP function. J Clin Invest, 115, 2673-8.

Wu HH, Wu JY, Cheng YW, et al (2010). cIAP2 upregulated by E6 oncoprotein via epidermal growth factor receptor/ phosphatidylinositol 3-kinase/AKT pathway confers resistance to cisplatin in human papillomavirus 16/18-infected lung cancer. Clin Cancer Res, 16, 5200-10.

Wuilleme-Toumi S, Robillard N, Gomez P, et al (2005). Mcl-1 is overexpressed in multiple myeloma and associated with relapse and shorter survival. Leukemia, 19, 1248-52.

Xiao C,Srinivasan L, Calado DP, et al (2008). Lymphoproliferative disease and autoimmunity in mice with increased miR-17-92 expression in lymphocytes. Nat Immunol, 9, 405-14.

Yamabe K, Shimizu S, Ito T, et al (1999). Cancer gene therapy using a pro-apoptotic gene, caspase-3. Gene Ther, 6, 1952-9.

Yang L, Cao Z, Yan H, et al (2003). Coexistence of high levels of apoptotic signaling and inhibitor of apoptosis proteins in human tumor cells: implication for cancer specific therapy. Cancer Res, 63, 6815-24.

Yerbes R, Lopez-Rivas A (2012). Itch/AIP4-independent proteasomal degradation of cFLIP induced by the histone deacetylase inhibitor SAHA sensitizes breast tumour cells to TRAIL. Invest New Drugs, 30, 541-7.

Yuan S, Akey CW (2013). Apoptosome structure, assembly, and procaspase activation. Structure, 21, 501-15.

Zhang S, Ding F, Luo A, et al (2007). XIAP is highly expressed in esophageal cancer and its downregulation by RNAi sensitizes esophageal carcinoma cell lines to chemotherapeutics. Cancer Biol Ther, 6, 973-80.

Zhuang J, Laing N, Oates M, et al (2014). Selective IAP inhibition results in sensitization of unstimulated but not CD40-stimulated chronic lymphocytic leukaemia cells to TRAIL-induced apoptosis. Pharmacology Res Perspect, 2, 6.

Zou H, Henzel WJ, Liu X, et al (1997). Apaf-1, a human protein homologous to C. elegans CED-4, participates in cytochrome c-dependent activation of caspase-3. Cell, 90, 405-13. 